\title{
Encounters with the Avant-Garde: Four Case Studies in the Reception History of Contemporary Flute Works (1971 to present)
}

Amanda Cook

Follow this and additional works at: https://researchrepository.wvu.edu/etd

\section{Recommended Citation}

Cook, Amanda, "Encounters with the Avant-Garde: Four Case Studies in the Reception History of Contemporary Flute Works (1971 to present)" (2016). Graduate Theses, Dissertations, and Problem Reports. 5393.

https://researchrepository.wvu.edu/etd/5393

This Dissertation is protected by copyright and/or related rights. It has been brought to you by the The Research Repository @ WVU with permission from the rights-holder(s). You are free to use this Dissertation in any way that is permitted by the copyright and related rights legislation that applies to your use. For other uses you must obtain permission from the rights-holder(s) directly, unless additional rights are indicated by a Creative Commons license in the record and/ or on the work itself. This Dissertation has been accepted for inclusion in WVU Graduate Theses, Dissertations, and Problem Reports collection by an authorized administrator of The Research Repository @ WVU.

For more information, please contact researchrepository@mail.wvu.edu. 
Encounters with the Avant-Garde:

Four Case Studies in the Reception History of Contemporary Flute Works (1971 to present)

\author{
Amanda Cook \\ DMA Research Project submitted \\ to the College of Creative Arts \\ at West Virginia University \\ in partial fulfillment of the requirements for the degree of \\ Doctor of Musical Arts in \\ Music Performance \\ Cynthia Anderson, MM, Chair \\ Andrew Kohn, PhD, Research Advisor \\ Nina Assimakopoulos, MM \\ Mikylah McTeer, DMA \\ Yoav Kaddar, $\mathrm{PhD}$
}

School of Music

Morgantown, West Virginia

2016

Keywords: Flute, Contemporary Classical Music, Avant-Garde, Reception History, Extended Techniques, George Crumb, Tōru Takemitsu, Karlheinz Stockhausen, Marcos Balter

Copyright 2016 Amanda Cook 


\begin{abstract}
Encounters with the Avant-Garde:

Four Case Studies in the Reception History of Contemporary Flute Works (1971 to present)
\end{abstract}

\begin{abstract}
Amanda Cook
Using reception history as a historiographical lens, this study traces the development and maturation of critical language used to describe selected flute works from 1971 to present that include extended playing techniques in addition to theatrical elements specified by the composer. Only English-language documentation is examined, and the majority of these items are reviews. The works used as case studies are George Crumb's Vox Balaenae (1971), Tōru Takemitsu's Voice (1971), Karlheinz Stockhausen's Flautina (1989), and Marcos Balter's Descent from Parnassus (2012).
\end{abstract}

The purpose of this study is two-fold: 1) Define the role of temporality in relation to the developmental arc of critical language used to describe contemporary classical flute works, and 2) examine the evolution of interactions between composers, performers, and audiencesespecially music critics - as it relates to the performance aesthetic of contemporary music and the communication of this repertoire through both performance and language.

The results of this study suggest that composers, performers, and audiences alike have all generally become more comfortable with the discussion of contemporary flute works over the past several decades rather than this familiarity specifically corresponding to the amount of time that a work has existed. This study also reveals an emergence of a common language used to identify and discuss extended techniques as well as the formation of a canon of what are considered to be standard extended techniques. 


\section{Acknowledgements}

Words cannot express my gratitude for my committee: Prof. Cynthia Anderson, Dr. Andrew Kohn, Prof. Nina Assimakopoulos, Dr. Mikylah McTeer, and Dr. Yoav Kaddar. Thank you for your guidance and encouragement throughout the process of this degree. I admire all of you for your professionalism and your generosity. Special thanks to Beth Royall for helping me locate the vast catalogue of source material represented in this document.

Thank you to my friends and family for your endless love and support over the past 10 years. To my mother, Barry, Mitch, Ian, and my grandparents, Ernest and Kathleen Lewis-I would not be the person or professional that I am today without you. 


\section{Table of Contents}

Chapter 1: Introduction to the Study 1

Glossary of Extended Flute Techniques 5

Chapter 2: George Crumb Vox Balaenae (1971) Reception History

Vox Balaenae Introduction $\quad 7$

$\begin{array}{ll}\text { The } 1970 \mathrm{~s} & 10\end{array}$

The $1980 \mathrm{~s} \quad 13$

$\begin{array}{ll}\text { The } 1990 \mathrm{~s} & 20\end{array}$

The 21st Century $\quad 24$

Chapter 3: Tōru Takemitsu Voice (1971) Reception History

Voice Introduction 34

$\begin{array}{ll}\text { The } 1970 \text { s } & 37\end{array}$

The $1980 \mathrm{~s} \quad 41$

The 1990s $\quad 44$

$\begin{array}{ll}\text { The 21st Century } & 46\end{array}$

Chapter 4: Karlheinz Stockhausen Flautina (1989) Reception History

Flautina Introduction $\quad 57$

The 1990s $\quad 59$

$\begin{array}{ll}\text { The 21st Century } & 64\end{array}$

Chapter 5: Marcos Balter Descent from Parnassus (2012) Reception History

Descent from Parnassus Introduction $\quad 72$

Reception History $\quad 75$

Chapter 6: Synthesis of Trends $\quad 82$

$\begin{array}{ll}\text { Bibliography } & 86\end{array}$ 


\section{Chapter 1: Introduction to the Study}

In his 2002 book The Flute, author Ardal Powell recognized the lack of a "detailed survey of new flute music since 1970 that does justice to the immense breadth and inventiveness of the new repertoire" and proposed that this formed "the topic of a book that has yet to be written." $\mathrm{A}$ review of the literature in preparation for this study reveals that this call still remains to be answered. There is a wealth of flute repertoire from the past 45 years, but there is little scholarship to reflect this abundance and diversity - the majority of the recent flute scholarship includes pedagogical treatises, performance guides specific to a single piece or composer, catalogues of flute works by a single composer, and introductions to the performance of extended techniques. While this existing scholarship is no doubt indispensable to the understanding and communication of these works from a performance and educational perspective, it does not address topics such as the critical reception of these works, the language used to describe these works, or the complex web of interactions between composers, performers, and audiences. The world of music criticism contains a wealth of potential sources that have yet to be fully explored in reference to contemporary classical flute music; these sources include newspaper articles, interviews, CD liner notes, album reviews, online magazine articles, blog posts, and podcasts. By considering these sources as they pertain to the reception history of contemporary classical flute works of the past 45 years, it is possible to begin placing these works within a greater societal context.

Using reception history as a historiographical lens, this study traces the development and maturation of English-language criticism used to describe selected flute works from 1971 to the present that include extended playing techniques in addition to theatrical elements specified by the composer. This study builds a reception history of each case study using only existing critical source material, and the majority of these sources are printed reviews. The works used as case studies are George Crumb's Vox Balaenae (1971), Tōru Takemitsu's Voice (1971), Karlheinz Stockhausen's Flautina (1989), and Marcos Balter's Descent from Parnassus (2012). For the purposes of this study, a documented performance of a case study refers to a performance for

\footnotetext{
${ }^{1}$ Ardal Powell, The Flute (New Haven: Yale University Press, 2002) 274.
} 
which a critical review exists, not a performance catalogued by the existence of a program. The case studies have been intentionally chosen for two reasons: first, the combination of extended playing techniques and theatrical components specified by the composer; second, composition dates ranging from 1971 to the present day representing three separate decades. The purpose of this study is two-fold. First, this study defines the role of temporality in relation to the developmental arc of critical language used to describe contemporary classical flute works. For the purposes of this study, temporality references the interrelationship between how long a work has existed and the general passage of time. Second, this study examines the evolution of interactions between composers, performers, and audience members - especially music criticsas it relates to the performance aesthetic of contemporary music and the communication of this repertoire through both performance and language. The study of the interaction between composers and performers is limited to the role of performers as influences on the compositional process, the role of performers as champions of music by composers who have died, and the role of performers as conduits of authentic statements and interpretations of composers' intentions.

For each of the selected case studies, the availability and diversity of literature is definitively linked to the geographic location of the composer and the work's composition date. This study only considers source material in English, thus there is more English-language criticism pertaining to the works by composers who live in the United States - George Crumb and Marcos Balter - than the works by Japanese composer Tōru Takemitsu and German composer Karlheinz Stockhausen. Regarding composition date, there is a greater abundance and diversity of source material pertaining to the works premiered in the 1970s: Crumb's Vox Balaenae (1971) and Takemitsu's Voice (1971). The early source material pertaining to the reception history of these works includes more newspaper reviews than works premiered in subsequent decades; there is a noticeable drop-off in newspaper reviews by the late 1980s/early 1990s that perhaps corresponds to the rise in internet technology and an increasing preference for online journalism. As a result, criticism pertaining to Flautina (1989) and Descent from Parnassus (2012) is largely composed of blogs, online magazines, and podcasts.

Crumb's Vox Balaenae produced the most substantial catalogue of source material; this abundance of English-language criticism is largely due to Crumb's American nationality and the 
work's status as the oldest composition in this study. Constructing a concurrent reception history of Takemitsu's Voice - composed in the same year-is only problematic regarding the Japanese premiere of the work: apparently, no English-language reviews exist. Otherwise, the amount of time the work has existed, along with the reviews of crucial early performances of the work in London by internationally-recognized flutist Aurèle Nicolet, have yielded a substantial amount of English-language criticism. Analyzing two conceptually-similar works composed in the same year provides a crucial foundation for comparing the developmental arc of critical language used to describe contemporary flute works.

After establishing the relationship between Vox Balaenae and Voice, the decision to include Descent from Parnassus and Flautina in this study was not only due to their unique combination of extended flute techniques and theatrical elements specified by the composer, but also their varied composition dates from subsequent decades. Analysis of Descent from Parnassus reveals a substantial collection of English-language criticism due to Balter's geographic location in Chicago and the Chicago premiere of the work. Comparing critical language used to describe Descent from Parnassus to critical language used to describe Vox Balaenae and Voice serves to discern whether the maturation of critical language is linked to the general passage of time or the age of a work. Flautina was the last piece to be added to this study, and though slightly problematic, serves as a crucial midpoint between the works from the early 1970s and Descent from Parnassus. The problem is that there is a paucity of Englishlanguage criticism pertaining to Flautina due to Stockhausen's German nationality and the almost-exclusive promotion of this work by Dutch flutist Kathinka Pasveer. However, the justification for adding the work to this study includes the renown of the composer, the stringent theatrical specifications by the composer, a composition date that falls approximately halfway between the other works in this study, and the suggestion that it is perhaps the "most approachable"2 of Stockhausen's flute works. Despite the difficulty in constructing an independent linear narrative of Flautina, the trends in the existing criticism serve to confirm findings from the other three case studies and provide crucial insight into the role of temporality

\footnotetext{
2 Leonard Garrison "Jennings and Wincenc in Concert." The National Flute Association Convention Chronicles, August 2011. http://www.nfaonline.org/Annual-Convention/Convention-Chronicles/ConventionChronicle.aspx?ChronicleID=142.
} 
as it relates to the developmental arc of critical language used to describe contemporary flute works.

The remainder of this introductory chapter is a glossary of extended flute techniques used in the selected case studies in order to provide concrete and consistent terminology to be used in the remainder of the research - while Vox Balaenae also contains extended cello and piano techniques, they are addressed and defined within the context of the chapter. Chapters two through five of this study focus on each case study individually and trace the critical language used to describe the work from the premiere - or as close to the premiere as possible - to the present day. Chapter six synthesizes the trends found in the exploration of each case study in order to draw conclusions about the maturation of critical language used to describe contemporary flute works over the past 45 years. The results of this study suggest that composers, performers, and audiences alike have all generally become more comfortable with the discussion of contemporary flute works over the past several decades. This trend is independent of the amount of time that a work has existed. This study also reveals an emergence of a common language used to identify and discuss extended techniques as well as the formation of a canon of what are considered to be standard extended techniques. 


\section{Glossary of Extended Flute Techniques}

aeolian tones: see residual tone.

air articulation: the act of using air to start the sound without the assistance of the tongue.

breathy tones: see residual tone.

flageolett: see whistle tone.

flutter tonguing: an effect produced by rolling the tongue (as one would do to pronounce the double "RR" consonant in Spanish) behind the teeth while producing a conventional flute tone. May also be produced by vibrating the uvula (as one would do while gargling).

glissando: a pitch bend that smoothly connects two pitches. For the flute, a glissando generally covers a small pitch space, such as a semitone or tone. May be produced by sliding the fingers across the open holes of the flute, bending the pitch with the embouchure, or a combination of the two.

harmonic: tones produced by overblowing a lower fundamental pitch.

“irregular spitting:" a specific reference to pizzicato articulation from Flautina. See also: pizzicato articulation.

key click: a percussive striking of the flute keys with the fingers that results in a pitched resonant tone without blowing air through the instrument.

kissing noises: a kissing sound produced while fingering a prescribed pitch that results in a pitched resonance.

microtone: an interval between the semi-tonal values of the equal temperament tuning system. Produced with special fingerings on a non-Kingma system flute. ${ }^{3}$

multiphonic: the sounding of two or more notes simultaneously. Produced by special fingerings and maneuvering the direction of the airstream between the desired pitches.

percussive articulation: articulation that relies on extended techniques including effects such as pizzicato articulation and tongue rams.

${ }^{3}$ The Kingma System flute is a standard Boehm mechanism with six extra keys added to produce the quartertones that are missing from the standard Boehm mechanism instrument. 
pizzicato articulation: a hard percussive articulation that results in a "popping" sound. Produced by placing the tongue between the lips, pressing down on the tongue firmly with the upper lip, and quickly pulling the tongue back inside the mouth.

residual tone: resonant but airy pitched sounds with no conventional flute tone produced by blowing the air over the embouchure hole.

"sing-flute:" a specific reference to singing while playing from Vox Balaenae. See also: singing while playing.

singing while playing: the simultaneous act of singing and producing flute tone. May be in unison, octaves, or harmony.

"speak-flute:" a specific technique from Vox Balaenae produced by whispering percussive syllables across the mouthpiece using a residual tone.

"toneless rushing:" a specific reference to residual tones from Flautina. See also: residual tone.

tongue click: a palatal click produced while holding the flute in normal playing position and fingering a prescribed pitch. Results in a pitched resonance.

tongue ram: a resonant pitched percussive effect produced by covering the embouchure hole with the lips and forcefully propelling the tongue between the lips to seal the opening.

timbral trill: a tremolo between different fingerings for the same pitch resulting in a rapid change of tone color.

whistle tone: a faint pitched whistling sound produced by blowing the air gently into the embouchure hole. 


\section{Chapter 2: George Crumb Vox Balaenae (1971) Reception History}

\section{Vox Balaenae Introduction}

Throughout the history of Western art music, large-scale developmental trends have continually been defined by the composers who broke from tradition. The outliers have come to shape our retrospectively-crafted musicological narrative arc that tells a story reliant on experimentation, novelty, and change. Based on observations of these trends, the two compositional concepts that seem to demand continual reevaluation and expansion are form and timbre, yet the ways in which composers employ these tools has also shifted over time. Timbre in particular has been realized by means of tuning systems, instrumentation, orchestration, extended techniques, and digital manipulation. George Crumb (b. 1929, Charleston, WV) often explores new sounds and timbres as applied to conventional instruments in his works, an approach to composition previously explored by Henry Cowell (1897-1965) and John Cage (1912-1992) whose novel approaches to the piano in particular can be seen in Crumb's works. A selfdescribed post-modernist composer, Crumb cites the echoing, reverberant sounds of the West Virginia river valley as an inherited acoustic that is reflected in many of his works. ${ }^{1}$ The use of electronic amplification in many of Crumb's works serves to capture this reverberation while enhancing the unconventional sounds and highlighting the evocative and often haunting nature of his music.

A prime example of this aesthetic is Crumb's Vox Balaenae [Voice of the Whale] for Three Masked Players (1971). This work was "inspired by the singing of the humpback whale, a recording of which the composer heard in 1969"'2 and provides commentary on both the lifespan of the earth and man's relationship with nature. Vox Balaenae exhibits Crumb's reverberant acoustic through electronic amplification of the entire ensemble: flute, cello, and piano. Rather than literally incorporating the whale song recording that served as the raison d'etre for this piece, Crumb requires the performers to imitate and approximate these sounds acoustically

\footnotetext{
${ }^{1}$ West Virginia Public Broadcasting, "A conversation with George Crumb” YouTube. Flash video file. https://www.youtube.com/watch?v=5xo8SHjTxpc (accessed April 16, 2015).

2 George Crumb, Preface to Vox Balaenae for Three Masked Players (New York: Edition Peters, 1971).
} 
through carefully notated extended techniques and timbral effects. In addition to the specificity of musical elements in this work, Crumb also recommends several theatrical components. In the introductory performance notes, he states that all performers should wear a black half-mask, which "by effacing a sense of human projection, will symbolize the powerful impersonal forces of nature (nature dehumanized)."3 He also suggests that if desired, Vox Balaenae may be performed under deep-blue stage lighting to further enhance the theatrical effect. Finally, he requires that the concluding phrase be performed silently in pantomime to create the effect of a fade out.

The formal structure of Vox Balaenae presents in three parts: "Vocalise (...for the beginning of time)," "Variations on Sea-Time," and "Sea-Nocturne (...for the end of time)." The opening "Vocalise" (marked in the score as "wildly fantastic, grotesque") is a cadenza for the flutist that exhibits the most overt references in this work to the singing of the humpback whale. Crumb accomplishes this likeness by requiring the flutist to sing and play at the same time. Perhaps the most "whale-sounding" effect occurs in passages where the flutist must cover the embouchure hole with his or her mouth so that the sung tone is projected through the tube of the flute. Fingering changes are specifically notated for these tones sung through the flute that produce a shimmering timbral trill. The "Vocalise" concludes with a parody quotation from Johann Strauss' Also Sprach Zarathustra, a tone poem inspired by Friedrich Nietzsche's philosophical novel Thus Spoke Zarathustra which concerns the role of man on earth. Following the Strauss quotation, the cello introduces the sea theme (marked "solemn, with calm majesty"). Crumb labels the ensuing "Variations on Sea-Time" using geological time periods:

"Archeozoic," in which only single-cell organism life existed, "Proterozoic," in which oxygen accumulated in the Earth's atmosphere and multi-cell organisms emerged, "Paleozoic," in which life forms transitioned from the ocean to the land, "Mesozoic," the age of reptiles, and "Cenozoic," the age of mammals and the arrival of man (marked "with an imminent sense of destiny"). Crumb signals this arrival of man with a restatement of the Zarathustra quotation before the return of the sea theme in the Sea-Nocturne (marked "serene, pure, transfigured"). Crumb remarks that this concluding passage is "couched in the 'luminous' tonality of B major

\footnotetext{
${ }^{3}$ George Crumb, Vox Balaenae for Three Masked Players.
} 
and there are shimmering sounds of antique cymbals...I wanted to suggest 'a larger rhythm of nature' and a sense of suspension in time."4 Figure 1 contains a complete listing of the extended techniques used throughout Vox Balaenae.

\begin{tabular}{|c|c|c|c|}
\hline \multicolumn{4}{|c|}{ Figure 1: Extended Techniques in Vox Balaenae } \\
\hline & Flute & Cello & Piano \\
\hline Vocalise & $\begin{array}{l}\text { "Sing-Flute" (singing } \\
\text { and playing } \\
\text { simultaneously), Flutter } \\
\text { tonguing, timbral trills }\end{array}$ & Tacet & $\begin{array}{l}\text { Muted strings, } \\
\text { glissando over strings }\end{array}$ \\
\hline Sea theme & Tacet & $\begin{array}{l}\text { Scordatura tuning, High } \\
\text { harmonics }\end{array}$ & $\begin{array}{l}\text { "Aeolian harp" effect } \\
\text { (glissando over strings) }\end{array}$ \\
\hline Archeozoic & Tacet & $\begin{array}{l}\text { "Seagull effect," quarter } \\
\text { tone trills, sul ponticello } \\
\text { glissando }\end{array}$ & $\begin{array}{l}\text { Chisel glissando on } \\
\text { strings, pizzicato } \\
\text { articulation }\end{array}$ \\
\hline Proterozoic & $\begin{array}{l}\text { "Speak } \\
\text { flute" (whispering } \\
\text { percussive syllables } \\
\text { over the mouthpiece) }\end{array}$ & $\begin{array}{l}\text { Percussive fingerings, } \\
\text { left hand pizzicato }\end{array}$ & $\begin{array}{l}\text { Pizzicato articulation, } \\
\text { apply paper clip to } \\
\text { vibrating strings }\end{array}$ \\
\hline Paleozoic & Harmonics & $\begin{array}{l}\text { Harmonics, sul } \\
\text { ponticello glissando, } \\
\text { natural harmonics } \\
\text { glissando }\end{array}$ & $\begin{array}{l}\text { Pizzicato articulation, } \\
\text { harmonics }\end{array}$ \\
\hline Mesozoic & none & none & $\begin{array}{l}\text { Glass placed over } \\
\text { strings from C4 to F5 }\end{array}$ \\
\hline Cenozoic & Flutter tonguing & $\begin{array}{l}\text { Sul ponticello tremolo } \\
\text { and glissando }\end{array}$ & $\begin{array}{l}\text { Glass placed over } \\
\text { strings from C4 to F5, } \\
\text { muted strings, glissando } \\
\text { over strings, harmonics }\end{array}$ \\
\hline Sea-Nocturne & $\begin{array}{l}\text { Whistling, timbral trills, } \\
\text { antique cymbals }\end{array}$ & $\begin{array}{l}\text { Whistling, antique } \\
\text { cymbals }\end{array}$ & $\begin{array}{l}\text { Glissando over strings, } \\
\text { harmonics }\end{array}$ \\
\hline
\end{tabular}

In the early years of Vox Balaenae's performance history, the timbral effects produced by the extended instrumental techniques in the score could hardly be defined by audiences and critics alike. Though the once shocking unconventionality of these timbral effects has faded over

\footnotetext{
${ }^{4}$ Da Capo Chamber Players, “Da Capo's 'Water Music,”’ da capo Program Notes, http://www.da-capo.org/ $\underline{\text { html/program notes } 1 . h t m}$ [accessed April 23, 2015].
} 
the past 45 years, an examination of the reception history of this work reveals that modern audiences crave a renewed sense of novelty from this seminal work. An increased familiarity with the score, knowledge of other works by Crumb, and a growing familiarity with the language of extended instrumental techniques in general have all contributed to this demand for reinvented novelty which has manifested in a heightened desire for the full theatrical package of the work including the masks and blue stage lights. Using reception history as a historiographical lens for examining this work demonstrates the ever-evolving perceptions of audience members through time as the vocabulary in critiques has shifted from primarily musical in the early years to increasingly extra-musical in the 21 st century. By tracing a linear narrative through attempted descriptions of the timbral effects from the earliest performances in the 1970s, overt negative criticism of the 1980s, the combination of technical and metaphorical language in the 1990s, and emphasis on creating a transcendent experience in the 2000s, a clear developmental arc of English-language criticism used to describe performances of this work emerges.

\section{The 1970s}

In the reception history of this work, the decade following the premiere was largely marked by attempts to decipher Crumb's timbral effects and compositional intent. The New York Camerata premiered Vox Balaenae on March 17, 1972 at the Library of Congress in Washington, DC. Varying accounts of the first performance from music critics demonstrates the blatant unfamiliarity with extended techniques and the resulting need to develop a vocabulary for discussing subsequent performances. Due to this critical emphasis on describing the unique sonic elements of this work, comments regarding the theatrical aspects of the performance seem merely tangential.

All graduates of the Manhattan School of Music, flutist Jayn Rosenfeld, cellist Charles Forbes, and pianist Glenn Jacobsen formed the New York Camerata in 1963, and the trio was hailed for their "sensitive polished chamber music playing." ${ }^{5}$ By the time of the 1972 Library of Congress concert, Paula Hatcher had replaced Jayn Rosenfeld as the flutist of the ensemble. Other works on the March 17th program included Trio for flute, violincello, and piano by

\footnotetext{
${ }^{5}$ UC San Diego, “New York Camerata to appear,” Press release, November 7, 1968.
} 
Bohuslav Martinů, Trio in F Major by Joseph Haydn, Sonatine (arranged by the New York Camerata) by Maurice Ravel, and Adagio, Variations, and Rondo on "Schöne Minka," Op. 78 by Johan Nepomuk Hummel. ${ }^{6}$ Though these other works on the program traverse a wide variety of styles ranging from the German classical tradition to French impressionism and Czech nationalism, they are all written in conventional notation that does not require instrumental techniques and timbral effects beyond the standard expectation for the ensemble.

Joan Reinhalter's review of this concert for the Washington Post claims, "There are very few pieces of new music to which I would be willing to commit myself without reservation... but I heard one last night." 7 Despite the lack of conventional tonality as a guide, it appears that the perceived formal structure of the work was clear to at least this particular reviewer based on her description of the work as being in three parts with variations labeled for geological ages, perhaps due to a clearly marked program, access to the score, or conversations with the composer or performers. The most revealing excerpt from Reinhalter's review, however, is her attempted descriptions of the timbral effects and extended techniques used in this work. She states that "the flute vocalise resembles Indian flute music for bamboo flute in its evocatively human sounds. Paula Hatcher may have been singing into the instrument at times. I am not sure." ${ }^{8}$ This statement suggests a failure to comprehend Crumb's use of extended flute techniques to imitate the singing of the humpback whale, hence the programmatic title Voice of the Whale. By citing Indian flute music, bamboo flutes, and human sounds, one could easily blame the reviewer for the missed connection between the title and the acousticallyapproximated whale song in the flute "Vocalise." However, it is also possible that the execution of the demanding and novel extended techniques could have been equally to blame.

Regarding the theatrical components of the premiere, Reinhalter cites masks and black robes worn by the performers (as opposed to merely the requested masks), and she concludes

\footnotetext{
${ }^{6}$ Library of Congress, "New York Camerata in Concert," Information bulletin, March 10, 1972. http:// www.mocavo.com/Library-of-Congress-Information-Bulletin-10-Mar-1972-Volume-31/648333/4 [accessed April 23, 2015].

7 Joan Reinhalter, "Voice of the Whale," Washington Post, March 18, 1972.

${ }^{8}$ Ibid.
} 
that these wardrobe choices kept both the performers' personalities and the formal concert context from "intruding on the music." " Lawrence Sears also reviewed this performance for the Evening Star and the Washington Daily News and did not view the theatrical components as necessary. While Reinhalter's review implies that the masks and robes enhanced the musical experience, Sears was left with the impression that the music itself could stand alone. His review emphatically claims, "Even if future performances are played in the nude, or wrapped in tin foil, Crumb's score will remain a powerful evocation, filled with pools of lyric inspiration to delight chamber music lovers for some time to come."10

After the premiere, audiences became quickly acquainted with the premise of Vox Balaenae. Though many reviews cite the theatrical components as effective, the majority of the writings on this work focus on developing concrete descriptions of Crumb's unique timbral effects and instrumental techniques. Examining several other newspaper reviews from 1972-1973 reveals a grappling for vocabulary in order to properly describe performances of this work. The Aeolian Chamber Players - consisting of Erich Graf (flute), Jerry Grossman (cello), and Walter Ponce (piano) — were one of the first performing ensembles other than the New York Camerata to program Vox Balaenae, and on October 10, 1972, they presented the work at The Town Hall (New York, NY). This was one of the first New York City performances of the work following the Washington, D.C. premiere seven months prior. Donal Henahan's review in the New York Times on October 12, 1972 demonstrates the same uncertainty displayed in Reinhalter's review of the premiere. While he does acknowledge that the ensemble imitated the recently-released recordings of whale songs with "eerie precision," he also perceived unintended non-oceanic references such as a "drone rather like that of an Indian tabla from the strummed piano strings, or melisma that might have come from a Moorish throat."11

A significant point of comparison in the maturation of critical language and development of vocabulary for discussing Vox Balaenae emerges from looking at reviews by the same critic.

\footnotetext{
9 Joan Reinhalter, "Voice of the Whale."

${ }^{10}$ Lawrence Sears, “Camerata Trio Plays in Dark," Evening Star and the Washington Daily News, March 18, 1972. In David Cohen, George Crumb: A Bio-Bibliography (Westport: Greenwood Press, 2002 ), 179.

11 Donal Henahan, “Crumb’s Touch,” New York Times, October 12, 1972.
} 
Donal Henahan also reviewed a performance by the New York Camerata at Alice Tully Hall (New York, NY) on April 5, 1973. Not only did Henahan have six months between reviews to become more familiar with the score, but the New York Camerata also conceivably had time to grow more familiar with the demands of this piece in order to present a more convincing performance. Henahan's 1973 review remarks that with the hall darkened, the "theatrical device worked extremely well, forcing concentration on his fragile harmonics, prepared-piano, jinglings, and other half-heard sonorities"12 The specific identification of harmonics, prepared piano, and additional sonorities shows tremendous development in the language used to discuss this piece as it is more musically descriptive and less reliant on simile-driven language.

\section{The 1980s}

The second decade of Vox Balaenae exhibited the most overt negative criticism of the work; reviews and writings from the 1980s address the potential inaccessibility of the work, overexposure, and the "gimmicky" theatrical effects. Regarding potential inaccessibility, William Furtwangler discusses a perceived esoteric quality in his review of a performance by Sara Stern (flute), Glenn Garlick (cello), and Lambert Orkis (piano) on May 29, 1980 in Charleston, SC at the Physicians Memorial Auditorium, a venue on the campus of the College of Charleston. He remarks, "Music of this type is championed by musical academicians and performers. They are rarely called for by audiences, unless the audiences are made up of musicians and academic composers." ${ }^{13}$ This seems to imply that Furtwangler felt the work could not survive outside of the academic sphere, and that it was too abstruse for lay audiences.

On the contrary, Edward Rothstein for the New York Times found the work "far from intellectually demanding." "14 He reviewed the Chamber Music Society concert at Alice Tully Hall on April 1, 1983; Paula Robison (flute), David Finckel (cello), and Samuel Sanders (piano) performed Vox Balaenae on a program that also included Weber's Seven Variations for Clarinet

12 Donal Henahan, “Inventive Voice of the Whale," New York Times, April 7, 1973.

${ }^{13}$ William Furtwangler, "20th Century Consort: Treasure Hunt," News and Courier (Charleston, SC), May 30, 1980. In David Cohen, George Crumb: A Bio-Bibliography (Westport: Greenwood Press, 2002), 183.

${ }^{14}$ Edward Rothstein,“Chamber Music Society Plays “Vox Balaenae,”” New York Times, April 4, 1983. 
and Piano in B flat, Op. 33, Mozart's Quintet in G minor, K. 516, and Beethoven's String

Quartet in C, Op. 59, No. 3. While Rothstein was complimentary of the performers' execution of Vox Balaenae - a "languorous, dreamy performance... with each player so sensitive to the work's demands that at certain moments instrumental timbres became nearly interchangeable"he experienced a "relaxed, contemplative passivity" in listening to the work rather than being actively engaged. ${ }^{15}$ Where Furtwangler's review insinuates that there is an audible level of complexity to Vox Balaenae beyond the realm of comprehension for non-music specialists, Rothstein appeared to find it merely pleasantly inconsequential. While there is nothing egregious about Rothstein's passivity in listening to the work, it does not reflect the type of active listening required in order to uncover the compositional complexities as suggested by Furtwangler. Aside from the polarization of opinions regarding the intellectual demands of the work, it appears that Rothstein did not enjoy the other performances on the program either, citing them as "without bite or drive" and "non-committal."16

With a quick upsurge in performances of Vox Balaenae following the premiere, redundancy and tiredness from repetition also served as a point of negative criticism. The Dreamtiger ensemble, consisting of Kathryn Lukas (flute), Rohan de Saram (cello), and Douglas Young (piano), among others, presented an East-West influenced program at The Roundhouse in London on November 23, 1981. Other composers on the program included Toshiro Mayuzumi, Douglas Young, Colin McPhee, and Iannis Xenakis. In her review for Tempo, Brigitte Schiffer remarks, “Crumb's Vox Balaenae, worn thin from over-exposure, added little to an otherwise entirely memorable evening." 17 It is noteworthy that a London performance of this work, as opposed to a United State performance, elicited this response from a music critic, thus demonstrating the international popularity and dissemination of Vox Balaenae within a relatively short timespan.

\footnotetext{
15 Edward Rothstein,"Chamber Music Society Plays 'Vox Balaenae.””

16 Ibid.

17 Brigitte Schiffer, “'East-West' by Dreamtiger,” Tempo, New Series, No. 136 (Mar., 1981) pp. 46-47 via http://www.jstor.org/stable/946384 [accessed April 22, 2015].
} 
The purportedly contrived nature of the whale song imitations and theatrical effects were also targets of negative criticism as seen in reviews by Heuwell Tircuit in the San Francisco Chronicle and John Rockwell in the New York Times. Tircuit attended a performance by Marya Martin — a leading contemporary flutist — an unidentified cellist, and Marilyn Thompson (piano) on December 4, 1983 at Veteran's Auditorium, now the Herbst Theatre of the San Francisco War Memorial and Performing Arts Center. Despite the renown of the flutist in particular, Tircuit was not convinced. He states, "Like the titles, the piece itself is heavily burdened with gimmicks. Much of the opening movement is given over to the literal parody of whale song, and indeed, Crumb is uncommonly successful in this artifice. But it goes on and on."18 The use of the word "parody" rather than "imitation" implies a perceived exaggeration and insincerity on Crumb's behalf. John Rockwell of the New York Times also alluded to a lingering skepticism in his review of the Santa Fe Chamber Music Festival's presentation of Vox Balaenae at the Metropolitan Museum of Art on December 13, 1989. He states that while Ransom Wilson (flute), Marcy Rosen (cello), and Jeffrey Swann (piano) made "22 minutes of wispy, eerie sound-colors... with the earnest gravity demanded of them," the overall impression of the techniques employed in the composition, though alluring, "seemed silly." ${ }^{19}$ Rockwell also notes that this "timid venture into avant-gardism...drove several of the Met's conservative audience-members from the premises." Rockwell's impression of this composition as "timid," "silly," and worthy of driving patrons from the venue paints a picture of Crumb as insincere and unsuccessful in his compositional intent similar to Tircuit's equally negative review.

In analyzing the language of Vox Balaenae criticism, two sources prove that performances of the work were not the only thing rife with gimmicks. The Washington Post ran an advertisement on October 2, 1981 for a performance of Vox Balaenae associated with the Dumbarton Concert Series. In addition to ticket and contact information, writer Jamie Gold includes the following kitschy description of the event: "With the use of amplified cello, piano

\footnotetext{
18 Heuwell Tircuit, “A Contemporary Voice is Soloists' Highlight," San Francisco Chronicle, December 6, 1983. In David Cohen, George Crumb: A Bio-Bibliography (Westport: Greenwood Press, 2002), 183.

19 John Rockwell, “Chamber Quintet’s Particular Program,” New York Times, December 17, 1989.
} 
and flute music and special lighting you feel as if you're rubbing fins with the whales." 20 Also in reference to the Dumbarton Concert Series — this time, seven years later-Joseph McLellan of The Washington Post reviewed the opening of their 1988 concert series and remarks, "There was something fishy about the way the Dumbarton Concert Series began its season Saturday night in the Dumbarton United Methodist Church, but it turned out to be a whale of a concert." 21 The sense of artificiality in these reviews by Tircuit and Rockwell is susceptible to the same criticism that condemned the allegedly forced nature of whale songs and theatricality in Crumb's work. In an ironic turn of events, the language used to describe Vox Balaenae in these two articles reflects the same gimmicks for which the composition was condemned.

The necessity and purpose of the theatrical effects was also called into question during this time. In the fifth edition of New Directions in Music (1989), author David Cope asserts that the absence of the black masks and blue lights does not detract from the music on a recording, thus perpetuating negative critiques of the theatrical aspects. He elaborates by explaining that "the music can easily stand alone and the visual aspects, though interesting in performance, are by no means essential to the work (i.e., the music retains its artistic identity without the visual complement)." 22 While this statement is not blatantly negative-in fact, it can be viewed as quite the compliment to Crumb's aesthetic - it assists in substantiating other criticisms of the theatrical elements.

However, opinions on the theatrical elements were not one-sided—rather, they polarized quite dramatically. Some interpreters of Vox Balaenae in the 1980s took Crumb's specified theatrical components as license to include a number of their own visual effects in addition to the black masks and blue lighting. On October 1, 1984, the experimental Operaworks troupe presented an all Crumb program including Night of the Four Moons, Ancient Voices of Children, and Vox Balaenae at the Larry Richardson Dance Gallery. Will Crutchfield reviewed this performance for the New York Times, and while he correctly asserts that many of Crumb's

\footnotetext{
20 Jamie Gold, “Vox Balaenae,” Washington Post, October 2, 1981.

21 Joseph McLellan, “Apple Hill: An Ode to The Ocean,” Washington Post, October 17, 1988.

22 David H. Cope, New Directions in Music, 5th ed. (Dubuque: WM. C. Brown Publishers, 1989), 258.
} 
compositions invite "theatrical experimentation," he additionally claims that Crumb's notes on Vox Balaenae "welcome further experimentation with dance, costume and mime."23 Upon thorough examination of the performance notes in the score, no such suggestions are overtly made or even loosely suggested, yet soprano Katherine Johnson and director Joel P. Casey devised their own staging for this one-woman show of Crumb compositions. Night of the Four Moons and Ancient Voices of Children both contain solo vocal parts in the score, but Johnson and Casey had to create additional theatrical components in order to include the vocalist in Vox Balaenae. Crutchfield recounts the performance as such:

It was mimed as a sort of summary of human evolution. Miss Johnson began wriggling limbless on her belly; gradually she gave herself fins, then arms, then the ability to crawl, stand, and finally (so it seemed) use a weapon. It didn't work, for this viewer at any rate: the music is slow, timeless, but the staging made it seem simply long, and limited the associations it could evoke. ${ }^{24}$

The addition of visual elements beyond those specified in the score by Crumb was seemingly detrimental to this particular performance. While Crumb's theatrical devices were devised in conjunction with the music in order to enhance the compositional intent and underlying concept of the work, the additional experimentation included here appears to have distracted from the music.

Aside from the negative criticism addressing the accessibility of the work, overexposure, and theatrical effects, a more technical, descriptive, and accurate language began to emerge in the 1980s and early 1990s, and this is once again best demonstrated by analyzing multiple reviews by the same critic. Just as Donal Henahan's two reviews for the New York Times in the 1970s showed increased ability to discuss Crumb's compositional techniques with repeated encounters, three reviews by Joseph McLellan in the Washington Post spanning from 1983-1993 demonstrate the effects of familiarity and repeated listenings on the continued developmental trajectory of language used to describe Vox Balaenae.

McLellan's first review of Vox Balaenae for the Washington Post was in April 1983. The Chamber Music Society of Lincoln Center performed the work in New York on April 1, 1983-

\footnotetext{
${ }^{23}$ Will Crutchfield, “Operaworks Performs 3 Pieces by Crumb,” New York Times, October 3, 1984. ${ }^{24}$ Ibid.
} 
the same performance that had been deemed "far from intellectually demanding" by New York Times critic Edward Rothstein — and proceeded down to Washington, DC for a performance of the same program at The Kennedy Center on April 2, 1983. The subject of McLellan's second review was the October 15, 1988 Dumbarton Concert Series season opener, previously cited for contrived puns referencing "something fishy" and "a whale of a concert." The performance featured the Apple Hill Chamber Players whose members included Bonnie Insull (flute), Paul Cohen (cello), and Eric Stumacher (piano) among others, and the program also included Schubert's “Trout” Quintet and two waltzes for strings by Dvořák. McLellan's third review of Vox Balaenae was a November 20, 1993 concert by the 20th Century Consort in the Hirshhorn Museum. Performers included Sara Stern (flute), David Hardy (cello), and Lisa Emenheiser (piano), and the program also featured Joseph Schwantner's Two Poems of Agueda Pizarro, Frank Bridge's Cello Sonata, and Villa-Lobos' Jet Whistle. Categorizing the text of these reviews into general impressions, flute techniques, piano techniques, and cello techniques best demonstrates the evolution of language over this ten-year span.

McLellan's first encounter with Vox Balaenae reminded him of works by Peter Schickele and Alan Hovhaness that also incorporate whale songs. However, he believed that Crumb took the use of whale songs a step further by "feigning the natural sound with human players and traditional instruments used in nontraditional ways." 25 The negative connotation associated with the word "feign" leads the reader to believe that Crumb's process of realizing whale-inspired sounds through acoustic instruments was artificial and insincere, especially when compared to the previously cited Schickele and Hovhaness works which use recorded whale sounds in conjunction with acoustic instruments. McLellan's review from ten years later paints a much different picture. He writes:

In the 22 years since George Crumb's "Vox Balaenae" ("The Voice of the Whale") was composed, musical taste has undergone some drastic changes and the postwar avantgarde has been unseated. But the exotic instrumental sounds of this music, inspired by oceanographers' recordings of whales singing, have remained as evocative as ever. ${ }^{26}$

\footnotetext{
25 Joseph McLellan, “Chamber Music Society of Lincoln Center,” Washington Post, April 4, 1983.

${ }^{26}$ Joseph McLellan, “20th Century Consort,” Washington Post, November 23, 1993.
} 
A small difference in word choice—swapping "feign" for "inspired by" — demonstrates a greater understanding of Crumb's compositional intent: Crumb did not intend to replicate whale songs using acoustic instruments; he sought to create gestures inspired by these recordings. McLellan notably found the combination of extended instrumental techniques used to suggest whale songs to be effective in retrospect ten years after his first review and 22 years after the premiere.

In an effort to describe the extended flute techniques used in Vox Balaenae, McLellan states in his 1983 review that "Paula Robison spun out long, wild, lonely melodies on her flute, and whispered almost intelligible words into it,"27 in his 1988 review, he states that "Flutist Bonnie Insull sang and talked into her instrument as well as playing it in the traditional way;" 28 and in his 1993 review, he describes "flutist Sara Stern vocalizing into her instrument."29 There is only one instance in Vox Balaenae where Crumb calls for spoken syllables in the flute part; in the "Proterozoic" variation, he uses a technique that he refers to as "speak-flute" where the syllables "Ko-Ki-Ka-Ku-Ka-Ki-Ko" are to be "whispered over [the] mouthpiece of the flute so that a faint tone is projected." 30 The more prominent technique, which is used extensively in the opening "Vocalise," is singing and playing simultaneously. While the whispering mentioned in the 1983 review and the singing and talking into the instrument cited in the 1988 review are more or less correct descriptions, vocalizing into the instrument as detailed in the 1993 review is perhaps the most all-encompassing description for the combined flute and vocal techniques required in the performance of this work.

Regarding the extended piano techniques in Vox Balaenae, McLellan states in his 1983 review that "Samuel Sanders leaned into his piano and stroked the strings gently, producing ripples, then waves of sound that hovered in the air;" 31 in his 1988 review, he states "pianist Eric

\footnotetext{
27 Joseph McLellan, "Chamber Music Society of Lincoln Center.”

28 Joseph McLellan, “Apple Hill: An Ode to The Ocean.”

29 Joseph McLellan, "20th Century Consort."

${ }^{30}$ George Crumb, Vox Balaenae for Three Masked Players.

31 Joseph McLellan, "Chamber Music Society of Lincoln Center."
} 
Stumacher bent over his instrument and strummed it like a harp;"'32 and in his 1993 review, he describes "Lisa Emenheiser Logan reaching into her piano to strum the strings into sounds like a stormy surf crashing on the shore."33 All three reviews only reference the "Aeolian harp" technique of reaching inside the piano and strumming the strings, perhaps because this is the easiest technique to visually detect. Without personally looking inside the lid of the piano, the other prescribed piano preparations would be difficult to decipher even for a trained musician. The 1983 review describes leaning into the piano and the 1988 review describes bending over the instrument, but the 1993 review explains that the performer reached inside the instrument, thus providing the clearest illustration of how the technique is produced.

The descriptions of the extended cello techniques do not demonstrate as significant a change over this ten year span because McLellan's reviews focus on the two techniques that are perhaps not so "extended:" harmonics and glissandi. In his 1983 review, he states "cellist David Finckel made his instrument squeak in eerie, birdlike harmonics;" in his 1988 review, he states “cellist Paul Cohen put aside his acoustic instrument for this number and slid his left hand slowly up and down the neck of an electric cello, producing weird, disembodied glissandi;" and in his 1993 review, he describes "cellist David Hardy spinning out eerie, disembodied, high-pitched glissandos." If one thing is for certain, it is that McLellan's perception of these techniques as "eerie" and "disembodied" did not change over ten years. While harmonics are considered to be a conventional - rather than extended — string technique, the inclusion of glissandi in the later reviews shows an increased awareness of the less conventional demands of the cello part. Still, there is no mention of the sul ponticello playing, left hand pizzicato, the "seagull effect," or scordatura.

\section{The 1990s}

If the 1980s could be categorized as a period of developing vocabulary in the midst of overt negative criticism, the 1990s could be summarized as the rise of combining technically descriptive language and metaphorical language. Whereas the number of reviews and

\footnotetext{
32 Joseph McLellan, “Apple Hill: An Ode to The Ocean.”

33 Joseph McLellan, "20th Century Consort.”
} 
documented performances of the work appear to have declined slightly, descriptions of the extended techniques used in the work became more accurate with a consistent descriptive vocabulary beginning to emerge. Woven into these increasingly accurate descriptions of the musical happenings in Vox Balaenae was a metaphorical language that attempted to capture the complete theatrical experience of the work. The two main narrative threads that emerge from the criticism of this decade are the shock factor of the work and noticeable references to the terms "language" and "vocabulary."

Martin Adams' 1999 review for the Irish Times provides the best general example of the critical language maturation during this decade. Adams attended the first concert of the Mostly Modern series at the Bank of Ireland Arts Centre in Dublin in November of 1999. Susan Doyle (flute), Martin Butt (cello), and Alison Thomas (piano) performed a program of electro-acoustic works including Benjamin Dwire's Crow for flute and tape, Roger Smalley's Echo II for cello and stereo tape delay system, and Vox Balaenae. Adams lists the instrumentation of Vox Balaenae as "flute, scordatura cello and prepared piano," and this is one of the first reviews to use the exact phrases "scordatura cello" and "prepared piano." 34 Whereas earlier reviews merely attempted to recount the effects produced by these modified instruments, Adams correctly identifies the modifications themselves. In addition to demonstrating an increased awareness of the extended instrumental techniques in the work, Adams also opts for an experiential description of the piece as a whole rather than dissecting the unique compositional vocabulary or the theatrical components. Regarding Vox Balaenae, he writes, "Its hinting at things, rather than quoting or illustrating them, is reinforced by its designation 'for three masked players'. There were no masks, but this sensitive performance was utterly absorbing." 35 From this description, Adams demonstrates an understanding of Crumb's intended musical allusions to whale songs, nature, and the passage of time-moreover, he demonstrates an understanding of the function of an illusion: to evoke an image or reference without explicitly stating it. This stands in stark

\footnotetext{
${ }^{34}$ Martin Adams, "Susan Doyle (flutes)/William Butt (cello)/Alison Thomas (piano) Bank of Ireland Arts Centre," The Irish Times, November 8, 1999.

35 Ibid.
} 
contrast to reviewers from the previous decade who interpreted Crumb's compositional approach as "feigning" or "parodying" these sounds from nature.

Two articles from the early 1990s present opposing viewpoints on the continued novelty of the extended instrumental techniques and theatrical elements in Vox Balaenae, and location might play a significant role in this dichotomy. The two reviewers in question are Charles McCardell for the Washington Post and Stephen Whittington for the Advertiser, an Australian publication. McCardell's review covers the March 12, 1991 Santa Fe Chamber Music Festival performance at the Kennedy Center; Ransom Wilson (flute), Marcy Rosen (cello), and Jeffrey Swann (piano) presented Vox Balaenae on the program which also included works by Haydn, Beethoven, and Smetana. Whittington's review covers the October 17, 1993 Music Chamber Players of South Australia performance at Elder Hall on the campus of Australia's University of Adelaide; Diana Harris, Elizabeth Koch and Jacqueline Curiel presented Vox Balaenae on the program which also included works by Mozart, Beethoven, and Martinů.

McCardell recounts the Washington, DC performance as such:

With the stage bathed in blue light, this threesome returned for George Crumb's "Vox Balaenae" ("The Voice of the Whale"), using amplification to simulate a cetacean song. Crumb's atmospheric effects no longer shock; hearing Wilson triple-tongue and sing into his flute, Swann pluck the piano strings and create bottle-neck guitar sounds, and Rosen bow icy harmonics is to experience the comfortably familiar. In view of the musicians' strong performance, familiar did not mean run of the mill. ${ }^{36}$

McCardell's opinion that the extended instrumental techniques in this work were not only "no longer a shock" but also "comfortably familiar" follows the critical language developmental trajectory of the preceding 20 years in the United States and United Kingdom. Regarding the specific techniques used in the work, he correctly identifies multiple tonguing, singing while playing, plucking piano strings, and harmonics, which demonstrates a maturation of vocabulary. Also, akin to Martin Adams suggestion that Vox Balaenae is "hinting at things" rather than quoting or illustrating them, McCardell's use of the word "simulate" is more in line with Crumb's compositional intent than descriptions from earlier performances.

Contrastingly, Whittington recounts the Australia performance two years later as such:

36 Charles McCardell, “Santa Fe Chamber Music,” Washington Post, March 18, 1991. 
This program was a startling combination of the classics - Mozart and Beethoven - with the neo-classical, folkloric style of Martinu and a blast from the Age of Aquarius in the shape of George Crumb. How well this combination hung together is open to question.

Just when I thought it was safe to go back in the water, along comes George Crumb's Vox Balaenae (Voice of the Whale) to haunt me again.

Crumb's spooky sound effects are capable of causing a frisson, and he goes for the emotional jugular with a simplistic palette of weird instrumental colors to illustrate his intentions.

Elder Hall on a Sunday afternoon is not quite the right setting to get the most out of a work like this, which needs a very theatrical staging, with appropriate lighting, for maximum effect. Diana Harris, Elizabeth Koch and Jacqueline Curiel were sympathetic interpreters who took the score's unusual demands in their stride. ${ }^{37}$

Perhaps the most revealing component of this review is the seemingly contradictory interplay of Whittington's demonstrated familiarity with the work and his critical commentary. The fact that he refers to the work as back to haunt him again — coupled with comments on the necessity of the staging and lighting for maximum effect —implies that this was not his first hearing of the work, yet he still refers to the performance as "spooky" and "weird" in addition to referring to the demands of the extended instrumental techniques in the score as "unusual." This is the first documented Australian performance of Vox Balaenae in this study, and while it is most likely not the first performance of the work on the continent, the language in Whittington's review is more reflective of American reviews from prior decades than contemporary American reviews at this time. This linguistic inconsistency brings issues of exposure and temporality to the fore. Whereas the general passage of time since the premiere of the work was identical across the globe, the language in Whittington's review suggests that exposure to the work and familiarity with the existence of the composition as a completed musical entity might have varied between the continent on which it was premiered and the continent on which it was performed in this particular instance. While this variation merely concerns one review of one performance within a substantially larger pool of source material, it does create a slight linear inconsistency in the developmental trends which otherwise suggest that composers, performers, and audiences alike

37 Stephen Whittington, “A Startling Assortment,” The Advertiser, October 19, 1993. 
became more generally comfortable with the discussion of extended instrumental techniques and theatrical elements over a series of decades rather than this familiarity corresponding to the exposure time and awareness of a work.

As one purpose of this study is to analyze the critical commentary used to describe contemporary flute works, it is remarkable that the terms "vocabulary" and "language" begin to appear in reviews during this time. In his review of the Philadelphia Orchestra Chamber Music Series concert at the Academy of Music Ballroom on January 21, 1996, Peter Dobrin for the Philadelphia Inquirer explains that Crumb's approach to Vox Balaenae "expands the vocabulary of the work's three instruments - flute, violin and piano-by amplifying them, making every small utterance audible." 38 Dobrin's reference to an expanded musical vocabulary is reflective of the expanding critical language vocabulary, thus creating an allusion to the concurrent musical and linguistic maturation. Similarly, Clive O'Connell for The Age reviewed the opening concert of the 1996 Reflective Space Festival—Australia's first electro-acoustic music festival. Elizabeth Barcan (flute), Elizabeth Haydon (cello), and Mark Knoop (piano) performed Vox Balaenae on a program that also included Stockhausen's Kontakte, Saariaho's Noa noa, Denis Smalley's Windchimes, and Martin Wesley-Smith's For clarinet and tape. Regarding Vox Balaenae, O’Connell remarks, "While there were moments when its language suggested Hovhaness, Moby Dick and Leviathan, the concluding Sea-Nocturne moved into the emotional world of Free Willy." 39 Aside from likening the Sea-Nocturne to a superficial feel-good family movie about the bond between a heartwarming orphan and an orca whale, citing a musical "language" in conjunction with literary references strengthens the connection between compositional technique and critical commentary as they both matured and developed over the general passage of time.

\section{The 21st Century}

If documented performances of Vox Balaenae declined slightly in the 1990s, this slide into minor obscurity did not last for long as there was a swift resurgence in performances at the turn of the 21 st century. With an increase in documented performances of this work came a new

\footnotetext{
38 Peter Dobrin, "Sights Accompany Sounds in Chamber Series," Philadelphia Inquirer, January 23, 1996.

${ }^{39}$ Clive O’Connell, “Stockhausen Makes Local Contact,” The Age, November 8, 1996.
} 
wave of criticism that explored the overall transcendent experience of the piece. A prevalent extra-musical concern emerged from the criticism of the early 21 st century, and this can perhaps be attributed to more widespread familiarity with the techniques and timbres in the score. The emergence of a more mainstream universal language for the discussion of the musical elements in Vox Balaenae eradicated the need for attempted personal descriptions and thus allowed audiences to focus on the presentation of the piece as a whole. This shift in critical commentary could also be attributed to the fading novelty of the extended instrumental techniques while the theatrical elements remained an uncommon practice, therefore satisfying audiences' desires for reinvented newness in performances of this work. The critical trends that have emerged over the past 15 years include the achievement of "classic" status, commentary on the complete experience of the work, promotion by prominent contemporary classical music performers, and comparison to other art forms.

When one refers to a literary or artistic work as a "classic," there is an implication of not only high quality but a particular type of excellence that has withstood the passage of time and remained among the best in the field; two reviews from the early 21 st century regard Vox Balaenae as having achieved this "classic" status. The first is Martin Snapp's preview of upcoming appearances in the San Francisco area by pianist Sarah Cahill. Of particular interest is the information pertaining to the Left Coast Chamber Ensemble performance of Vox Balaenae at the War Memorial Building that occurred on March 3, 2003. In this section of article, Cahill regards Vox Balaenae as "a real classic of the early '70s avant garde." ${ }^{40}$ It is noteworthy that in this particular article, the critic allows the performer to attest to the legitimacy of the composition; Snapp defers to Cahill's intimate knowledge of the work instead of providing his own descriptions of Crumb's demands. He takes advantage of the performer's ability to discuss the extended instrumental techniques in the work and gives her musical training, vocabulary, and intimacy with the composition a platform to reach a wider audience through printed text. The result is a particularly detailed account of how the performers create the unique timbral effects in the work, especially the piano effects. Cahill explains, "The cello creates eerie whale sounds, the

40 Martin Snapp, “Cahill Cornucopia Comes to Music Fans in March,” Contra Costa Times, February 28, 
flutist whispers into her flute while playing, and I strum the strings, pluck them while scraping a chisel across them, buzz them with paper clips and mute them with my fingers." 41 This is one of the first mentions of the required chisel and paper clips as tools for modifying the piano timbre, and it comes from the performer herself.

The second article to address the heightened status of Crumb's work is Allan Kozinn's New York Times review of Carnegie Hall's Making Music series at Zankel Hall on October 27, 2008. Kozinn not only regards Vox Balaenae as an "avant-garde classic," but he also attests to the resurgence in documented performances of Crumb's works in the 21st century: “George Crumb and his music are getting a second wind these days. In the 1970s Mr. Crumb's colorful, idiosyncratic chamber works were all the rage...but by the mid-1980s Mr. Crumb seemed to have faded from view." 42 Kozinn goes on to recognize Crumb's recent compositional output and the reappearance of his older works on concert programs. His description of the performance by Tara Helen O’Connor (flute), Priscilla Lee (cello), and Molly Morkoski (piano) is also remarkably accurate; Kozinn describes "bending, microtonal flute and cello pitches," "insidethe-piano writing," "a stylized version of whale song," and "a refracted quotation of Strauss's 'Also Sprach Zarathustra'."43 The details of Kozinn's description are significant because this is one of the first specific mentions of microtonality and the Strauss quotation in the critical commentary of the work.

Another narrative thread in 21 st century critical reviews of Vox Baelaenae is a particular focus on the experience of the work as a whole rather than an isolation of the musical and theatrical components. A more accurate and consistent language for describing the extended instrumental techniques in the work allowed for a more concise recounting of the performance; this new-found succinct brevity created more space in critical reviews for impressions of the music, the execution of the performers, and the atmospheric experience. In February 2000, Elissa Poole for the Globe and Mail published an article on Crumb in advance of Makrokosmopolitan,

\footnotetext{
41 Martin Snapp, "Cahill Cornucopia Comes to Music Fans in March.”

${ }^{42}$ Allan Kozinn, “Return to Crumb's World, With Crumb Along for the Ride," New York Times. October
} $28,2008$.

43 Ibid. 
a three-day Crumb festival presented at Wilfrid Laurier University in Waterloo, Ontario. While this article is not a concert review, Poole recalls her first encounter with Crumb's music through Vox Balaenae. Her descriptions of the extended techniques in the work demonstrate a new accurate and concise vocabulary; she cites "whistling cello harmonics, reverberations produced inside the piano, flute echoes and watery oscillations between true and harmonic fingerings; whispered speech," but she also addresses the "many, strange and ephemeral, almost too beautiful" sounds that create the composite musical experience. ${ }^{44}$ Also crucial to this review is the inclusion of a remark by the composer himself regarding his compositional intent. She quotes Crumb as saying, "If my music comes off as a collection of sound effects, it absolutely fails... That's not the intention at all. The hope is that it is organically integrated." 45 Poole gives the composer's voice a platform other than program notes or the concert stage just as other reviews during this time consulted performers of contemporary music. Understanding compositional intent subsequently aids in comprehension of musical language and the communication of avantgarde techniques through performance and language.

Joan Reinthaler, the critic for the Washington Post who reviewed the premiere of Vox Balaenae at the Library of Congress in 1971, reviewed a performance of the work almost 30 years later. On February 20, 2000, National Musical Arts performed Mozart's A Musical Joke, Barber's Sonata for Cello and Piano, Op. 6, and Vox Balaenae at the National Academy of Sciences Auditorium. Her review of the Vox Balaenae premiere had likened the flute writing to Indian bamboo flute music, and she was not sure if the flutist was singing into her instrument; contrastingly, her 2000 review commends Alice Weinreb (flute), David Teie (cello), and Patricia Gray (piano) for their "artistry and dignity" while correctly identifying "humming into the flute and popping down percussively on the finger holes," "glissandi in harmonics" from the cello, and maneuvering inside the piano to "strum and pluck and insert and remove rattling objects."46

\footnotetext{
44 Elissa Poole, “Composer on a mission; George Crumb’s work—always about something-was fashionable 20 years ago. Now he is back on radar screens," Globe and Mail, February 2, 2000.

45 Ibid.

46 Joan Reinthaler, "From National Musical Arts, a Blue Light Special," Washington Post, February 22, 2000.
} 
In addition to the drastic maturation of Reinthaler's ability to identify and describe the extended instrumental techniques in the work, she also comments on the "ceremonial nature" of the black masks, blue light, and pantomime of the last musical gesture while asserting:

In other hands this could be pretty hokey, but in Crumb's music this theatricalism adds to the timelessness of an idiom that he has invented for himself, one that features an exquisite sense of delicate sound and texture that seems to hover motionlessly in time. ${ }^{47}$

Reinthaler's metaphorical description of the comprehensive experience of Vox Balaenae in this review provides a stark contrast to her review from thirty years prior which mostly consisted of grappling for language to describe the novel timbral techniques on a first hearing.

Other experientially-driven reviews from the 21 st century come from Rowena Smith and Guy Dammann for The Guardian and Joyce Tamer for Telegram \& Gazette. Smith reviewed the opening of the Edinburgh Contemporary Art Trust's 30th anniversary season; the program included a series of premieres and culminated in a performance of Vox Balaenae by Richard Craig (flute), Su-a Lee (cello), and Simon Smith (piano). Reviewer Smith regards Vox Balaenae as "an atmospheric work displaying multiple influences...though the overall effect is of a unified piece." 48 The use of the word "atmospheric" and the deliberate reference to the "overall effect" of the work demonstrates an increasing concern for capturing the comprehensive experience of the work. Dammann's 2010 review of a performance by the Chroma Ensemble attempts to address this same aesthetic. He describes the whale song inspiration, masks, amplification, and a "range of techniques novel at the time of its creation," then subsequently reflects:

On paper it sounds like a deeply suspicious exercise in hippy kitsch, but heard live it rarely fails to bowl one over. This is less due to Crumb's success in depicting the ancient sadness that runs through our encounters with whales than the work's seamless musicality: peel away Crumb's web of symbols and you are left with a beautifully proportioned and beguiling set of variations, and a powerful sense of flow between instruments. ${ }^{49}$

47 Joan Reinthaler, "From National Musical Arts, a Blue Light Special."

48 Rowena Smith, “New Music Experience, Queen’s Hall, Edinburgh 4/5,” The Guardian, October 31, 2009.

49 Guy Dammann, “Chroma chamber ensemble_review,” The Guardian, November 8, 2010. 
Joyce Tamer's review for Telegram \& Gazette follows in similar fashion. On November 10, 2014, the Worcester Chamber Music Society presented a concert that included Ravel's Jeux d'eau and Piano Trio in A Minor, Górecki's String Quartet \#1, Already it is Dusk, and Vox Balaenae. Tamer correctly identifies singing into the flute, the "seagull" harmonic effect on the cello, and piano glissandi, string dampening, and placing glass along the strings as well as noting the black masks, blue lights, amplification, and pantomime specified by Crumb. Of the closing pantomime, she remarks that it is "a highly effective ending, which, unfortunately, was marred by an overly enthusiastic audience member." ${ }^{50}$ Alongside the mature musical vocabulary of these three reviews is an extra-musical concern as demonstrated by the use of words such as atmospheric, unified, flow, ethereal, and other-worldly to describe the composite whole of the extended instrumental techniques and theatrical effects.

The promotion of contemporary classical music by performers and ensembles specifically dedicated to the genre also influenced the critical reviews of Vox Balaenae in the 21 st century. Particularly impactful on not just Vox Balaenae but the entire new music scene was the emergence of the ensemble eighth blackbird: a Chicago-based "Pierrot ensemble" sextet formed in 1996. In 2004, eighth blackbird released Beginnings: an album devoted to Daniel Kellogg's Divinum Mysterium and Crumb's Vox Balaenae. Alan Kozinn reviewed the album for the New York Times, and his discussion of Vox Balaenae contains a plethora of metaphorical and extramusical language. He cites the "explosive Vocalise... representing the creation of the universe," a "sublimely meditative Messiaenesque Nocturne," and evocations of whale song in "eerily glassy cello slides," and though he emphasizes the risk that "theatricality and pictorialism will overshadow the inventiveness" of the composition, he asserts that that "while the players here draw the pictures and create the contrasts the composers demand, it is their superb musicality and interpretive vigor that bring these pieces to life." ${ }^{51}$ Kozinn leaves the reader with the powerful imagery of the performers bringing these scores to life through a mere audio recording. He suggests that —in the absence of the "theatricality and pictorialism" usually present in live

\footnotetext{
${ }^{50}$ Joyce Tamer, “WCMS sparkles with 'Water Games,” Telegram \& Gazette, November 17, 2014.

${ }^{51}$ Allan Kozinn, Review of Beginnings by eighth blackbird, New York Times, June 27, 2004.
} 
performances of this work - the outstanding musicianship displayed on eighth blackbird's audio recording of just the musical elements in the score is enough to evoke a visual image.

Richard Scheinin for the San Jose Mercury News had the opportunity to hear members of eighth blackbird perform the work live on February 5, 2005 at Kanbar Hall in San Francisco, and his description of the work blends technical music language with metaphorical language:

Barth sang through her flute while clacking keys and holding long whooshing tones, a modal wail of the whale. Then came piano: a rumble of bass notes and gentle zhooms strummed zither-like inside the instrument, more underwater noises, before the amplified cello's entrance with long bowed harmonics, conjuring the humpback's high-pitched, faraway singing. 52

Rather than describing the extended instrumental techniques and overall affect separately, Scheinin blends musical and extra-musical vocabulary to address the complete audience experience. He likens singing through the flute to the voice of the whale, the inside-the-piano writing to a zither, and the cello harmonics to distant, high-pitched whale song. By providing comparisons to other instruments or sounds from the natural world. Scheinin is able to communicate the composite experience of the extended techniques, theatrical effects, and composer intent. To summarize the experience of Vox Balaenae, he writes, "It was eerie: the illusion of music rising straight from the natural world, physical sounds that aren't really knowable." 53 Rather than attempting to describe all of the extended techniques used in the work in explicit detail, Scheinin is content to recognize their inherent mysteriousness and their contributions to the theatrical nature of the work without further dissection.

Reviewers also began comparing elements of Vox Balaenae to other musics or art forms in the 21 st century. Drawing these parallels effectively illustrates a connection to something more commonplace and more likely to resonate with a reader than the avant-garde niche market of contemporary classical music. Pierre Ruhe for the Atlanta Journal-Constitution creates several such connections in his review of the Atlanta Chamber Players concert on April 1, 2001 at the Rialto Center. In addition to Vox Balaenae, the program-which focused on musical impressions 2005 .

\footnotetext{
52 Richard Scheinin, “Tight, Fearless Sextet's Musical Declaration,” San Jose Mercury News, February 8,
} 53 Ibid. 
of nature-included Maurice Durufle's Prelude, Recitatif et Variations and Schumann's Piano Quartet in E-flat Major. Ruhe begins by comparing the complexity of contemporary classical music to advanced ecology: "While ecologists seek to explain the complex web of life in its habitat, poets and composers are usually content to gaze in simple awe." 54 Ruhe's suggestion that the admiration of avant-garde music is similar to viewing complex ecology in awe brings the arguments of Milton Babbitt's seminal essay Who Cares If You Listen to mind. Decades prior, Babbitt proposed that perhaps the academic genres of music composition had reached a critical point of complexity beyond the average listener, but he viewed the recognition of this divide as liberating rather than a restriction. In his essay, he states:

Why refuse to recognize the possibility that contemporary music has reached a stage long since attained by other forms of activity? The time has passed when the normally welleducated man without special preparation could understand the most advanced work in, for example, mathematics, philosophy, and physics. Advanced music, to the extent that it reflects the knowledge and originality of the informed composer, scarcely can be expected to appear more intelligible than these arts and sciences to the person whose musical education usually has been even less extensive than his background in other fields. 55

While there is something to be said for the complexity of Crumb's compositional language, Ruhe draws a connection between this complexity and the ecological themes in the work to illuminate the components of the work that would be more familiar to an audience without an extensive music education. He insinuates that it is possible to regard the constructive aspects of contemporary music with awe while still being able to comprehend the extra-musical elements of Crumb's compositional intent. Next, Ruhe compares Crumb's compositional language to the illustrations of famed childrens' book illustrator and writer Maurice Sendak. He writes, "Crumb's music often reminds me of Maurice Sendak's illustrations: the muted colors; the scary, whimsical, fantastical imagery; the ideas that operate at several levels of sophistication." 56 By drawing a visual and literary parallel to a pop culture icon best known for his book Where the 2001.

${ }^{54}$ Pierre Ruhe, "Chamber Players tap into nature's rhythms," The Atlanta Journal-Constitution, April 2,

${ }^{55}$ Milton Babbitt, “Who Cares if You Listen?” High Fidelity Magazine 8, no. 2 (1958).

56 Pierre Ruhe, "Chamber Players Tap into Nature's Rhythms." 
Wild Things Are, Ruhe allows the reader to imagine how a sonic representation of these familiar images might sound.

David Vance for the Sydney Morning Herald draws a connection to the film industry in his review of the Australia Ensemble's concluding concert of the 2001 season; the works on the program all related to various animals: Haydn's Lark Quartet, Messiaen's Le merle noir, Schubert's “Trout” Quintet, and Vox Balaenae. Vance explains Crumb’s underlying environmental message in Vox Balaenae with a reference to Stanley Kubrick's iconic 1968 science fiction film 2001: A Space Odyssey. He states, "It is quite deliberate that Crumb offers a distorted parody of the fanfare figure from Strauss's Zarathustra, suggesting as Kubrick had done in his film 2001: A Space Odyssey, the damage done by human intervention in the natural world." ${ }^{57}$ Referencing such a culturally-familiar film provides a context for Crumb's imitation of whale songs and allusions to the passage of time on earth. Of the complete experience of the work, Vance calls Vox Balaenae an "enchanting, extraordinary sound world, haunting in its beauty. That such massive creatures as whales could be so subtly expressive in their singing holds the key for music of infinite tenderness, but also of noble power." 58 The sonic imagery conjured by the words "enchanting," "haunting," and "noble" address the impression left by Crumb's composition in lieu of analyzing the details of its construction.

Joe Banno for the Washington Post simply compared Vox Balaenae to other musics rather than invoking other art forms. On November 15, 2005, Toshiko Kohno (flute), David Hardy (cello), and Lambert Orkis (piano) presented Vox Balaenae in the Terrace Theater of the John F. Kennedy Center for the Performing Arts in Washington D.C. on a program that also included Mozart's Trio in C, K. 548 and Franck's Piano Quintet. Banno's review of this concert draws compelling parallels to music of the past and the present while attempting to describe this seemingly contradictory other-worldly experience:

The resulting soundscape evokes everything from Balinese gamelan to 1960s audio-tape experiments, from Meredith Monk's extended vocal techniques to Harry Partch's

\footnotetext{
57 David Vance, "All things bright and beautiful hit the stage for a finale to remember," Sydney Morning Herald, October 16, 2001.

58 Ibid.
} 
homemade instruments — all filtered through a haunting, meditative, decidedly aquatic sensibility.

Performing under the deep-blue stage lights the composer requests for the piece, Orkis, Hardy and flutist Toshiko Kohno were clearly working hard to fulfill the score's unconventional demands. But they were so in touch with the composer's idiom that any focus on the mechanics of music-making was soon replaced by the wonder of hearing instrumental textures that sounded at once ancient and new-minted, nature-generated and startlingly human. ${ }^{59}$

In likening Vox Balaenae both to music which preceded it and music which followed it simultaneously, Banno marks the entire existence of the work - as opposed to isolated performances of it—as transcendent.

American composer, conductor, and educator Russell Steinberg recalls "'It'll never last"” was what I was told in a composition seminar during the 70's on the topic of George Crumb's 1971 trio for electric flute, cello, and piano titled Vox Balaenae." ${ }^{60}$ However, it has lasted, and examining the reception history of Vox Balaenae illuminates the ever-evolving language used to describe not only the work itself but also the experience of attending a performance. In the years following the premiere, the theatrical elements enhanced the musical components, but the unique timbral effects were the most compelling factor. Now, these previously-criticized theatrical effects seem to be expected from modern audiences in order to perpetuate the newness of the experiential whole. From attempted descriptions of the timbral effects in the 1970s to the negative criticism of the 1980s, the combined technical and metaphorical language of the 1990s, and the extra-musical descriptions of a complete transcendent experience in the 21st century, Vox Balaenae has challenged audiences and critics alike to reinvent the vocabulary used to discuss this work, just as these same audiences and critics have demanded reinvented novelty from performers.

59 Joe Banno, “At Kennedy Center, A Whale of a Recital,” Washington Post, November 15, 2005.

${ }^{60}$ Russell Steinberg, “'Meta-Counterpoint' in George Crumb's Music: Exploring Surface and Depths in Vox Balaenae (Voice of the Whale)." In George Crumb \& The Alchemy of Sound, edited by Steven Bruns and Ofer Ben-Amots (Colorado Springs: Colorado College Music Press, 2005), 211. 


\section{Chapter 3: Tōru Takemitsu Voice (1971) Reception History}

\section{Voice Introduction:}

When considering the multi-cultural exchange of musical ideas, a prominent narrative thread in the history of Western art music emerges: the interplay of Eastern and Western musical styles. The usual direction of influence has been Eastern influence on Western composers, and perhaps the most notable example of recurring influence is the characteristic harmonic and timbral properties of the gamelan — a collection of instruments indigenous to southeast Asia — as seen in the works of composers including Claude Debussy (1862-1918), Erik Satie (1866-1925), John Cage (1912-1992), and more recently, Steve Reich (b. 1936). Among the various Asian influences upon the entire realm of concert music, the compositional language of self-taught Japanese composer Tōru Takemitsu (1930-1996) stems from his earliest musical encounters, which consisted of solely traditional Japanese music. Firmly rooted in an Eastern musical aesthetic from a young age, Takemitsu's approach to composition was thus a product of the opposite direction of multi-cultural influence: Western influence on Eastern musical styles.

Takemitsu gained national and international recognition as Japan's leading composer during his lifetime. Though Western music was banned in Japan during World War II, exposure to recordings while completing chores for the military as a young schoolboy and radio broadcasts during his subsequent time spent in the hospital rehabilitating from tuberculosis served as his introduction to Western art music. ${ }^{1}$ His unique musical language represents a synthesis of varied styles and influences - he explained in a 1981 interview that he admired the music of Debussy, Webern, John Cage, Boulez, and Berio, and that this wide-ranging interest and admiration of Western musical styles was likely the reason why he "never restricted [his music] to a single idiom." "The resulting synthesis of these diverse influences was an approach to composition that blended Western instruments and avant-garde ideology with traditional Japanese instruments and music.

\footnotetext{
${ }^{1}$ Donald Dierks, “Music Changed His Life,” San Diego Union, March 15, 1981.

2 Ibid.
} 
Throughout his lifetime, Takemitsu enjoyed long and fruitful collaborations with three musicians in particular for whom he specifically composed and dedicated works: flutist Aurèle Nicolet, oboist Heinz Holliger, and harpist Ursula Holliger. Of particular interest and importance to flutists is Takemitsu's work with Nicolet — the products of this relationship include Eucalypts I (1970) for flute, oboe, and harp (premiered by Nicolet); Eucalypts II (1970) for flute, oboe, and harp (dedicated to and premiered by Nicolet); Voice (1971) for solo flute (commissioned by and dedicated to Nicolet); And Then I Knew 'twas Wind (1992) for flute, viola, and harp (commissioned by, dedicated to, and premiered by Nicolet); and Takemitsu's last composition: Air (1995) for solo flute (dedicated to Nicolet on his 70th birthday and premiered in a tribute to the composer). While Takemitsu composed a number of flute works with no special relation to Nicolet — namely Toward the Sea for alto flute and guitar, I Hear the Water Dreaming for flute and orchestra, Masque for two flutes, and Itinerant for solo flute - the trend of composers working with specific trusted performers became increasingly common as demonstrated by such relationships as Karlheinz Stockhausen and Kathinka Pasveer (Chapter 4) or Marcos Balter and Claire Chaise (Chapter 5).

In examining contemporary classical flute works that include extended playing techniques and theatrical elements specified by the composer, Takemitsu's Voice emerges as a historically-significant work in the repertoire. The composition includes an array of Western extended instrumental techniques including microtones, singing while playing, key clicks, "pizzicato" articulation, flutter tonguing, multiphonics, glissandi, timbral trills, and growling in addition to techniques intended to resemble the sound of Japanese shakuhachi and nohkan flutes including forceful air articulations, breathy tones, and special fingerings that change the timbre of the written pitch. The theatrical element specified by Takemitsu is text recitation that is interspersed between the demanding extended techniques. Voice was originally published in 1971, but the current Salabert Editions version was prepared in collaboration with flutist PierreYves Artaud and published in 1988. In the first edition of this work, the composer recommended the use of microphones in order to amplify some of the more subtle effects, but he no longer felt it was necessary in the 1988 edition. The piece is also written in proportional notation which 
allows for the music to be presented as a series of gestural concepts rather than strictly-rhythmic ideas.

In addition to the revolutionary technical demands of this work, Voice pairs Japanese influences and musical elements with a decidedly-Western instrument. Takemitsu references techniques specific to the nohkan - the flute used in Japanese Noh theater-and the shakuhachi throughout the work, yet requires these techniques to be realized on a Western flute. Takemitsu also achieves multi-cultural synthesis linguistically through the poetry used in this work-drawn from "Handmade Proverbs" by Shuzo Takiguchi, the following text is presented in both French and English: "Qui va la? Qui que tu sois, parle, transparence!” [Who goes there? Speak, transparence, whoever you are!]

The decision to include Voice in this study was largely due to its status as a significant benchmark in the history of avant-garde flute works, but an examination of the reception history of this work — particularly in the early years_ proves challenging when only considering sources in English due to the shortage of English-language reviews. However, promotion of this work by Nicolet — an internationally-recognized flutist — and early performances of this work in London provide enough of an English-language critical foundation on which to base a reception history narrative. Also significant in the decision to include Voice in this study is the composition dateVoice and Vox Balaenae were both composed in the same year, thus providing a clear point of comparison concerning the role of temporality in the discussion of the critical reception history of contemporary classical flute works. The majority of early English-language reviews of Voice cover the first performance of the work by Aurèle Nicolet in London; these reviews mostly mention the work as an afterthought, as it was a short solo flute work on an all-Takemitsu program that contained much larger compositions as the centerpiece. However, though easily cast aside in these early reviews, a study of the reception history of this work over the past 45 years reveals a shift in perception from Voice as an unintelligible-or perhaps worse, unimpressionable - product of the avant-garde to Voice as a bravura showpiece. A clear developmental arc of critical language used to describe performances of this work emerges through examination of the scant mentions of the work in the 1970s, negative criticism of the 
1980s, decline in performances during the 1990s, and resurgence as a virtuosic display of extended techniques and theatricality in the 21 st century.

\section{The 1970s}

Though Nicolet commissioned Takemitsu to write Voice, he did not perform the premiere of the work-Nicolet's first documented performance of the piece was nearly two years after the premiere. Takemitsu composed Voice in a single day on April 8, 1971, and Japanese flutist Ryû Noguchi premiered the work on June 9, 1971 at the 6th Cross Talk concert in Tokyo, Japan. ${ }^{3}$ James Siddons' bio-bibliography of Takemitsu cites this performance by Noguchi as the premiere but does not list any English-language reviews of this performance. Upon further investigation, no English-language reviews of the premiere were found. The small handful of reviews from this decade tend to merely mention Voice as a passing reference, and - in lieu of a lengthy critical discussion of the work - provide background information on Takemitsu's influences and his fusion of Eastern and Western musical elements.

The earliest English-language source in this study is John Rockwell's Los Angeles Times review of the "Encounters" contemporary music series concert on February 8, 1972 at Beckman Auditorium on the campus of California Institute of Technology in Pasadena, CA. The allTakemitsu program included Kyoto, a short film by Kon Ichikawa with music by Takemitsu; prerecorded performances of Stanza II for solo harp, ring modulator, and tape and of Cassiopeia for solo percussionist and orchestra; and live performances of Eclipse for biwa and shakuhachi, Stanza I for mezzo soprano and chamber ensemble, and Voice, performed by Sheridon Stokes, an accomplished Hollywood recording studio musician. Over half of the text in Rockwell's review serves to introduce the reader to Takemitsu as a composer, and the discussion of the performance primarily concerns the larger chamber works on the program. In his introductory remarks on Takemitsu, Rockwell describes him as a composer who "writes in a dizzying variety of styles, influenced by everything from serialism to near-comfortable chromaticism to Japanese tradition to a plethora of forms of post-serialism," the trouble being it is "a little hard to see where his real

\footnotetext{
3 James Siddons, Tōru Takemitsu: A Bio-Bibliography (Westport: Greenwood Press, 2001) 102.
} 
personality lies." ${ }^{\prime 4}$ Rockwell suggests that Takemitsu's synthesized influences were too reflective of other composers and styles and therefore easily dismissed for the perceived absence of distinguishing compositional traits - this sentiment is directly reflected in Rockwell's perception of Voice. In reference to both Voice and Stanza I, he writes, "Both the other two live pieces Tuesday sounded derivative, particularly the solo flute effort "Voice." "T This dismissive remark is the only mention of Voice in the entire review, yet even in its brevity it manages to reflect Rockwell's impression of Takemitsu as a composer with many influences and a subsequent lack of a distinctive compositional aesthetic. Rockwell found Eclipse to be the most successful work on the program — admittedly due to the "exoticism" of the Japanese instruments — and he did not attempt to describe the sounds and compositional techniques of the other works on the program.

The remainder of the reviews from the 1970s concern the first documented performance of this work by the dedicatee, Aurèle Nicolet. Nicolet performed Voice on a Music Digest concert at the Round House in London on May 6, 1973; the program was once again dedicated entirely to the works of Takemitsu including Distance for oboe and sho, Stanza II for harp and tape, Eucalypts II for flute, oboe, and harp, Eclipse for biwa and shakuhachi, Piano Distance for solo piano, and the simultaneous playing of two graphic score works: Corona and Munari by Munari. William Mann reviewed the performance for The Times; Dominic Gill reviewed the performance for The Financial Times; and Leslie East reviewed the performance in the July 1973 issue of Music and Musicians. Similar to the "Encounters" concert in Los Angeles in 1972, these reviews primarily attempt to describe Takemitsu's compositional aesthetic with little critical commentary regarding the compositions themselves - particularly Voice, a short solo flute work. However, the combination of these three reviews provides a decent portrait of Nicolet's rendition of Voice.

William Mann's review for The Times is the only review of the three to attempt to describe the extended instrumental techniques in Voice; of the composition, he writes, "Takemitsu regularly extends the conventional range of his chosen instruments. The flute (Aurèle Nicolet, the Richter of his instrument - what shading, what tone!) in Voice plays chords, and

\footnotetext{
4 John Rockwell, “Encounters with Takemitsu,” Los Angeles Times, February 10, 1972.

5 Ibid.
} 
taps, and blows air, and sings through the instrument." ${ }^{\prime 6}$ Here, Mann captures multiphonics, key clicks, breathy tones, and singing while playing, albeit not with technically descriptive music terminology. However, his attempted description in his own words provides a fairly accurate account while grappling for vocabulary to discuss these novel techniques. Mann also uses the word "extends" to describe Takemitsu's compositional demands without specifically referring to “extended techniques" yet still manages to capture the intent of extending the instruments' capabilities beyond the realm of standard technique. Finally, he briefly commends Nicolet's prowess in the form of shading and tone, but the reference to Richter is unclear; Mann could have been alluding to visual artist Gerhard Richter or pianist Sviatoslav Richter. Regardless, Mann seemed to be impressed with Nicolet's performance.

Dominic Gill's review of the Round House concert for The Financial Times provides even less insight regarding Voice; he merely provides passing commentary and states, "French flautist Aurèle Nicolet played Voice for solo flute with great élan before joining with Heinz and Ursula Holliger for Eucalypts II for flute, oboe, and harp." 7 The execution of the performer is the sole focus of the critical language used to describe the work, but while the review lacks details about the composition, Gill compensates by providing striking insight into his perception of Takemitsu's compositional style; he describes the quality of Takemitsu's music as "elusive: not something one must 'understand' but perhaps rather accept and absorb" and draws a connection to Western composers who have looked East for inspiration, namely Stockhausen and Cage. ${ }^{8}$ By alluding to the complexity of Takemitsu's music and placing him within the same realm as such unconventional inventors as Stockhausen and Cage, this review sets an important precedent that perhaps there is a crucial and novel experiential component to Takemitsu's sound world.

Leslie East's review of the Round House concert in the July 1973 issue of Music and Musicians provides perhaps the best blend of critical commentary about Takemitsu's aesthetic,

\footnotetext{
6 William Mann, “Takemitsu: Round House,” The Times, May 7, 1973.

${ }^{7}$ Dominic Gill, “Takemitsu,” The Financial Times, May 8, 1973.

8 Ibid.
} 
the composition itself, and the execution by the performer, yet it is still within the limited scope of a few sentences. East writes:

Nicolet also had his own solo, Voice (1971), in which the performer breathes human life into the full paraphernalia of modern technique and sonority. The parentage (Berio's Sequenze [sic]) of Voice may be obvious, but Nicolet's persuasive, delicate shading and the piece's own vibrant cogency gave it a unique and compelling physical presence.

In Voice and Distance, Takemitsu's origins have a tangible sound-outlet - the sho in Distance and the breathy quality of Japanese flutes in Voice.

East's commentary generally mentions modern flute techniques and sonorities - not to the extent of the attempted descriptions of extended techniques in Mann's review, but East at least attempts to provide a basic explanation of the work (unlike Gill's review). East even goes so far as to suggest that Voice is reflective of Luciano Berio's Sequenza I for solo flute (1958). In fact, the timbral language and palette of extended techniques in Voice are far more adventurous and novel than Sequenza I - the major parallels between the two works are the use of multiphonics, key clicks, and proportional notation, though it is doubtful that the use of proportional notation is an audibly perceptible trait. Regarding Nicolet's performance of the score, East and Mann both reference the "shading" of Nicolet's tone which suggests a successful realization of the strictlynotated timbral demands of the score; East and Gill both address the energy of Nicolet's physical demeanor; and East alone addresses Nicolet's ability to convincingly communicate the score in performance. Finally, East draws an East-West connection in Takemitsu's music by identifying the timbral influence of Japanese flutes as realized through Western extended techniques in Voice.

Though the reviews from the 1970s cover a wide range of topics including background information on Takemitsu, his varied influences, an East-meets-West amalgamation of styles, suggested precursors to Voice in the flute repertoire, outstanding musicianship demonstrated by Nicolet, and attempted descriptions of the extended techniques in the work, they do not dedicate much space to the discussion of the piece itself. Perhaps even more glaring is the complete lack of critical commentary on the theatrical elements of the work; there is not a single mention of the interwoven text recitation, and Mann's description of "singing through the flute" is the only review that suggests the combination of flute tone and the human voice. With a title such as 
Voice, it is surprising that none of the reviews included in this study address the spoken poetry. While some of the reviews from this decade provide small glimpses into the experience of this work, an introduction to Takemitsu and exploration of his East-West aesthetic appears to have taken precedent over descriptions of how this aesthetic is realized in his compositional style.

\section{The 1980s}

The opening to David Smoller's March 11, 1981 profile on Takemitsu in the Los Angeles Times emphatically exclaims, "Is Tōru Takemitsu an oddball?"9 While Smoller clarifies that Takemitsu himself admits to being "unusual," this portrait of Takemitsu as out-of-the-ordinary serves as the perfect preface to critical language used to describe Voice in the 1980s. The most prominent new critical language trend to surface during this decade was overt negative criticism, yet a recognition of the theatrical vocal elements of Voice also emerged. Some trends from the previous decade continued into the 1980s including descriptions of Takemitsu's background and influences, paltry mentions of Voice, and presence of language pertaining to extended techniques

- however, this language shifted from attempted descriptions of the techniques to mere mentions that still lacked a mature and consistent vocabulary.

In a review for the New York Times, Edward Rothstein continues the features of the dismissive and diminutive mentions of Voice from the 1970s while expressing the new wave of negative commentary of the 1980s. Rothstein reviewed a program of microtonal music presented by the ensemble Newband at Symphony Space in New York on April 25, 1982; in addition to Voice, the program included Charles Ives' Three Quartertone Piano Pieces, a transcription of J.S. Bach's Es Ist Genug for a 31-tone octave percussion instrument, Harry Partch's Two Studies in Ancient Greek Scales, Dean Drummond's Columbus, Joan La Barbara's Silent Scroll: An Image of Entrophy, and Ezra Sims' Two for One. Rothstein only dedicates a single sentence in his review to Voice: “Toru Takemitsu's Voice exploited a wide variety of flute sounds in a work that had its share of cliché." 10 Rothstein does not attempt to identify or describe these flute sounds 1981.

${ }^{9}$ David Smoller, “Composer Takemitsu Breaks Mold, Reconciles Cultures,” Los Angeles Times, March 11,

10 Edward Rothstein, “Concert: ‘Microtonal' by Newband,” New York Times, April 29, 1982. 
nor does he explain why he found the work to be cliché. With no further commentary, it is difficult to reconcile Rothstein's criticism with the far-from-mature critical vocabulary of the preceding decade; in light of the fact that the critical reviews from the 1970s could scarcely describe the extended techniques in the work, Rothstein's insinuation that the use of these techniques was overdone or unoriginal seems unexpectedly negative considering the minimal passage of time.

Jonathan Saville for the San Diego Reader also found Voice problematic, but his review of a Takemitsu and Berio program at University of California, San Diego on March 3, 1981 explains his negative criticism in great detail. The concert followed Takemitsu's month in residence at UCSD, and the composer attended the performance. The all-Takemitsu first half of the program included For Away for solo piano; Waves for clarinet, horn, two trombones and bass drum; Water Ways for clarinet, violin, cello, two harps, two vibraphones, and piano; and Voice. Saville explains that Voice struck him as "difficult of access," but rather than making such a claim with no further explanation like Rothstein, he includes his reasoning:

The problem appeared to be the excessive proliferation of peculiar coloristic devices, which, in the virtuoso performance of flautist Bernhard Batschelet, called so much attention to themselves and to the instrumentalist's brilliance of execution that it was hard to keep one's mind on the music these effects were meant to serve. I suspect that repeated listening would remove the distracting qualities of those shouts, hums, taps, breathy timbres, wavering pitches, and so on... ${ }^{11}$

Saville starts by referring to the extended techniques as "peculiar coloristic devices," and while he categorizes these techniques as odd, his use of the word "coloristic" recognizes that they serve a timbral purpose in the work. He also commends the execution by the performer-which is a continuing trend from the 1970s - and explains that Batschelet's brilliant rendering of the score proved to be a distraction from the overall effect of the work. Regarding the extended techniques, Saville mentions a list of vague sound effects, but this list does little to describe actual extended techniques; hums could refer to singing while playing, taps could refer to key clicks, and wavering pitches could refer to timbral trills or microtonal passages, but it is unclear. However, despite the nondescript nature of most of Saville's word choices, "breathy timbres" is an accurate

\footnotetext{
11 Jonathan Saville, “Sound of Structure,” San Diego Reader, March 12, 1981.
} 
description of the Japanese flute-inspired sounds. Perhaps the most important part of Saville's review is the last sentence - he proposes a solution to his negative critical points in stating that repeated listenings could conceivably allow for a more thorough understanding of the score with the novelty of extended techniques on a first hearing removed.

Though the negative criticism of the 1980s was the most prominent and consistent narrative thread to emerge during this decade, an increased recognition of the vocal elements of Voice was simultaneously developing. Nicholas Kenyon for The Times covered the last week of the 1984 Aldeburgh Festival; Takemitsu was the featured contemporary composer, and his programmed works included A Flock Descends into the Pentagonal Garden for orchestra performed by the London Sinfonietta; Rain Spell for flute, clarinet, piano, harp, and vibraphone; Orion for cello and piano; and Voice performed by flutist Sebastian Bell. Though Kenyon only briefly mentions Voice, he regards the "breathings and noises" as "splendidly done."12 The mention of "breathings" at least suggests the presence of vocal technique beyond the normal air intake required for playing the flute. More thorough is Paul Griffes' review of "Music Projects with Bernas" at the Almeida for The Times. Organized by British conductor Richard Bernas in February 1988, the concert included performances of Dmitry Smirnov's The Visions of Coleridge, Oliver Knussen's Trumpets, Mark Anthony Turnage's Lament for a Hanging Man, Bruno Maderna's Dialodia, and Voice. While Griffes' review largely falls in line with the negative criticism of the decade - "If this was a slightly disappointing evening, the fault must lie with the choice of music rather than the presentation, which was altogether admirable"- he describes Voice as "enticingly played, whispered and breathed by Nancy Ruffer."13 The use of the words "whispered" and "breathed" clearly describes theatrical vocal elements outside of the realm of standard tone production sounds.

The review that best captures all of the critical themes of the 1980s combined is Kenneth Herman's review in the San Diego Union of the University of California, San Diego concert

\footnotetext{
12 Nicholas Kenyon, “Aldeburgh Festival,” The Times, June 19, 1984.

13 Paul Griffes, "A strong team / Review of Music Projects with Bernas at the Almeida," The Times, February 15, 1988.
} 
previously referenced in Jonathan Saville's review for the San Diego Reader. Regarding Voice, Herman states:

Two works that exploited extended instrumental techniques were "Voice" for solo flute and "Waves" for clarinet, assisted by two trombones, French horn and percussion...

... "Voice" seemed strident and heavy-handed. Bernhard Batschelet rendered the work with force and the "vocal ornaments" with admirable grace - it is not easy to shout text in the midst of a difficult section of flutter-tounguing [sic]. ${ }^{14}$

Herman's critical language used to describe this performance includes mention of extended techniques, negative criticism of the composition, and recognition of the theatrical vocal elements. First, he uses the phrase "extended instrumental techniques," thereby effectively categorizing the out-of-the-ordinary sounds and timbral effects in Voice. He also correctly identifies flutter tonguing as a technique employed in the work. However, his negative criticism declares that the extended techniques were "exploited" and that the overall effect was "strident and heavy-handed." Herman seems to insinuate that the performer navigated the score well despite the trite nature of the composition. Finally, he makes direct reference to "vocal ornaments" and subsequently explains that shouting text in the midst of playing is a significant component of the work - this review from 1981 is one of the earliest reviews to explain this crucial theatrical component with such clarity. Herman's review therefore summarizes the critical trends of the 1980s in a mere few sentences: limited mentions of Voice, commending the execution of the performer, use of language to suggest extended techniques, and recognition of the theatrical vocal elements, all colored by a negative critical lens.

\section{The 1990s}

The 1990s marked a sharp decline in documented performances of Voice - a survey of English-language criticism for the purposes of this study only produced two sources that directly reference the work. While documented performances of this work from 1971-1990 predominantly occurred in London and on the west coast of the United States, the two reviews from the 1990s included in this study are from Ireland and Canada. Martin Adams for the Irish

\footnotetext{
${ }^{14}$ Kenneth Herman, “Delicacy Marks UCSD Concert,” San Diego Union, March 4, 1981.
} 
Times reviewed a concert titled "Oriental Wind" which was presented on October 31, 1996 at the Bank of Ireland Arts Centre in Dublin as part of the Bank of Ireland Mostly Modern Series; in addition to Voice, the program also included Kazuo Fukushima's Ekagra for alto flute and piano; Ferroud's Trois Pieces Pour Flute; Paul Hayes's Lost in Suite for piano; David Loeb's Six Preludes for solo piccolo; and George Rochberg's Between Two Worlds for flute and piano. In Canada, Elissa Poole for the Globe and Mail reviewed a "Tōru Takemitsu Remembered" tribute concert on February 20, 1997 at the Glenn Gould Studio as part of the New Music Concerts series; in addition to Voice, the program included Masque for two flutes; Itinerant and Air for solo flute; Stanza for harp and tape; Bryce for two percussionists, two harps, and alto flute; and And then I knew 'twas Wind for flute, viola, and harp. Robert Aitken - artistic director of New Music Concerts and an accomplished Canadian contemporary flutist — organized the concert in addition to performing, which accounts for the large number of flute-centric compositions on the program. Though these two reviews only briefly mention Voice, they both use critical language to describe characteristics of Japanese music as communicated through a decidedly-Western lens.

Martin Adams' review regards Voice as an obvious display of modernism. The term modernism as applied to music implies an attempt to break from tradition while still recognizing developmental trajectories of the past. In order to justify this label, Adams explains that the work is "forcefully episodic and a-tonal, with progress defined by contrasts of material in a way which eschews Western notions of beginnings and endings." 15 In this instance, Adams suggests that Takemitsu attempts to break from tradition through a non-Western formal arrangement of motivic material while carrying forth traditions of the past in his realization of these non-Western ideas through atonal harmony and the ability to maintain a loosely-episodic structure. Elissa Poole's review also focuses on the incorporation of traditional Japanese elements in Voice but frames them within the context of modern flute technique rather than modernism as a musical ideal. While Adams attempts to place the non-Western influences in Voice within a larger genredriven narrative context, Poole contextualizes these elements within the specific and technicallydescriptive language of extended flute techniques. Her short mention of the work is densely-

\footnotetext{
15 Martin Adams, "Susan Doyle (flutes)/Patrick Zuk (piano) Bank of Ireland Arts Centre," The Irish Times, November 6, 1996.
} 
packed with information. She states, "Voice, with its myriad vibratos, quartertone trills, multiphonics, key clicks and simultaneous vocalizations, was evocative of traditional Japanese music for shakuhachi flute."16 Poole correctly identifies microtonality, multiphonics, key clicks, and vocalization techniques with concise, accurate, and mature critical vocabulary. Regarding non-Western influence, Poole agrees with Adams that Voice is evocative of Japanese music, but while Adams links Japanese influence to formal design, Poole links Japanese influence to the timbral elements of the work as realized through extended flute techniques.

Though there is a scarcity of source material included in this study from the 1990s, the two reviews that are present serve as an important bridge between the critical commentary of the 1980 s - characterized by gradually-developing vocabulary and recognition of theatrical vocal elements in the wake of negative criticism - and the critical commentary of the 21 st century. Analysis of a small sample of reviews from the 1990s reveals a continued maturation of critical language used to identify and describe extended flute techniques as well as a heightened emphasis placed on the Japanese-inspired theatrical elements of the work. These performances and their subsequent reviews served as a precursor for a resurgence of documented performance in the 21 st century, and with it, a fully-matured critical vocabulary that allowed reviewers to address both musical and extra-musical concerns of Voice.

\section{The 21st Century}

The new wave of criticism that accompanied a resurgence in performances of Voice in the 21 st century exhibited an increasingly extra-musical concern, particularly referencing the work as a virtuosic showpiece and the overall experience created by the theatrical elements. The dramatic increase in documented performances could have been the result of a renewed interest in Takemitsu's work following his death in 1996, but a few well-respected contemporary flutists also adopted the work as part of their permanent repertoire — namely Paula Robison and Leonard Garrison. The sources of critical commentary also diversified after the turn of the 21 st century; whereas the majority of the source material prior to 2000 consisted of newspaper reviews, CD

\footnotetext{
16 Elissa Poole, “Tribute to Takemitsu Showcases Decades of Musical Innovation," The Globe and Mail, February 22, 1997.
} 
reviews and artist interviews joined the pool of critical commentary in this century. The use of a consistent and mature vocabulary of extended flute techniques created enough space in the critical reviews of this time for new and unique narrative threads to emerge: the notion of virtuosity, the promotion of Voice by specific performers, and an increased extra-musical emphasis on the theatrical elements of the work.

The reviews of the 21 st century that focus on the virtuosic nature of Voice seem to fall into two categories: 1) reviews that commend both the virtuosity of the performer and the virtuosity of the composition and 2) reviews that commend the virtuosity of the performer despite the composition. A review that falls into the former category is Jean Hasse's September 2010 review for the Bristol Post of an album release concert presented by Katherine Bryan (flute) and Scott Mitchell (piano) at St. George's Bristol; the program included Hüe's Fantasie, Franck's Sonata, Poulenc's Sonata, Barber's Canzone, Lowell Liebermann's Sonata, and Voice. Regarding Bryan's performance of Voice, Hasse remarks:

Katherine Bryan's technique is at a very high level, her playing is strong and confident, with great control of breath, fingering and smooth phrasings. She excelled in Tōru Takemitsu's haunting piece Voice, with sliding notes, harmonics, vocalising and fluttersa highlight of the concert, and played in total darkness! ${ }^{17}$

With no negative criticism of Voice - rather, Hasse found it to be the high point of a program which included many well-loved standards from the repertoire-Hasse highlights Bryan's virtuosity and writes nothing to suggest disapproval of the composition. Hasse also captures some of the extended instrumental techniques while bringing special attention to the theatrical vocalizations, yet the mentions of sliding notes (glissandi), harmonics, and flutters (flutter tonguing) exhibit vague and approximate language that are not indicative of the fully-matured 21 st century critical vocabulary seen in other reviews during this time.

Contrary to Hasse's view of Voice, Jay Nordlinger for the New York Sun viewed virtuosity as the only redeeming factor of his encounter with the work. On March 7, 2006, flutist Dora Seres presented a concert at Carnegie Hall's Zankel Hall as part of the Young Concert Artists performance series. In addition to Voice, the program also included Reinecke's Sonata "Undine"

17 Jean Hasse, "Flautist has an Extensive Repertoire," The Bristol Post, September 9, 2010. 
for flute and piano; Sigfrid Karg-Elert's Sonata Appassionata for solo flute; Weber's Trio in G minor for flute, cello, and piano; Taffanel's Fantasie on "Der Freischutz" for flute and piano; and Lowell Liebermann's Sonata for flute and piano. Rather than attempting to paraphrase, it is most revealing to read Nordlinger's entire discussion of Voice unaltered:

After intermission, this variety show of an evening continued with a second unaccompanied work: "Voice," by Tōru Takemitsu. This piece calls on the flutist to make any number of sounds, some of them not so purty. (But that is not the point: Extraordinary communication is.) The sounds the flutist makes include spoken words words in at least two languages, French and English. (I may have missed another, in the flutey mayhem.) The flutist also taps his instrument, or her instrument, making yet more sounds.

"Voice," like other Takemitsu pieces, is supposed to enchant, amaze, bewitch. I must say it had zero effect on me, but that could have been a matter of mood. In any case, Ms. Seres executed the piece very well, even brilliantly. ${ }^{18}$

It is important to note here that the New York Sun-launched in 2002 as an alternative to the New York Times - has been cited as a respected employment opportunity for aspiring young journalists. ${ }^{19}$ In the case of Nordlinger's review, "young" and "aspiring" unfortunately seem to manifest as informal and uninformed as both his overly-conversational tone and his lack of maturity in describing the extended techniques in the work serve to undermine his critical opinion. His perception that the effects produced by the extended techniques were "not so purty" is philistine at best, and his only attempt to defend this claim results in phrases such as "flutey mayhem" and "taps his instrument." However, despite his negative criticism of Voice-no matter how unsubstantiated - he regards the execution of the piece as brilliant in spite of the composition.

An examination of the critical language used to describe Voice in the 21 st century also illuminates two performers in particular who either performed the work on more than one documented occasion or recorded the work: Paula Robison and Leonard Garrison. Critical reviews of Paula Robison's performances perpetuate the notion of Voice as a virtuosic showpiece

18 Jay Nordlinger, “A Poised and Capable Young Flutist,” The New York Sun, March 9, 2006.

${ }^{19}$ Frank Ahrens, “Under Threat of Closing, N.Y. Sun Hunts for Capital,” Washington Post, September 4, 2008. 
while also demonstrating a mature critical language. Criticism pertaining to Leonard Garrison's interpretation of Voice thrusts his extensive study and preparation of the composition to the fore and largely focuses on his command of the challenging techniques. However, whether addressing Robison as the virtuoso or Garrison as the well-informed proficient technician, the language used in both scenarios suggests a desperation to legitimize and canonize a decades-old product of the avant-garde that remains challenging to performers and audiences to this day.

In the first decade of the 21 st century, Paula Robison had two documented performances of Voice in less than a year. In 2005, the Library of Congress hosted "Mirror of Tree, Mirror of Field: The Life and Music of Tōru Takemitsu:" a small festival dedicated entirely to the works of Takemitsu. Robison performed Voice in addition to And I Knew 'twas Wind for flute, viola, and harp and Air for solo flute on October 8, 2005 in Coolidge Auditorium as part of the festival; Stephen Brookes reviewed the performance for the Washington Post. The program also included Distance de Fee for violin and piano and Stanza II for harp and tape. Robison performed the work again a year later as part of a solo recital at Carnegie Hall's Weill Recital Hall on September 15, 2006; Bernard Holland reviewed the performance for the New York Times. The program also included Dutilleux's Sonatine Chaminade's Concertino, Michael Tilson Thomas' Notturno, and Martinů’s Sonata, all for flute and piano.

Brookes' review of the Library of Congress Takemitsu festival for the Washington Post correctly identifies almost all of the extended techniques used in Voice; he lists "multiphonics, timbral trills, key clicks, microtonal slides, shouting and whispering and hissing." ${ }^{20}$ The only extended techniques that are notably missing from this list are those pertaining to articulation — "pizzicato" articulation and flutter tonguing — and techniques intended to emulate the characteristic sound of Japanese flutes such as forceful air articulations and breathy tones. Brookes' list otherwise paints a rather accurate picture of the blended extended flute techniques and theatrical vocal techniques detailed in the score. Regarding Robison's performance of Voice, Brookes suggests that "perhaps the most extraordinary moments of the evening were in Robison's bravura performance of 'Voice,' a spectacular tour de force for solo flute from 1971."21

\footnotetext{
${ }^{20}$ Stephen Brookes, “Tōru Takemitsu, Timelessly Contemporary,” The Washington Post, October 11, 2005. ${ }^{21}$ Ibid.
} 
The use of the terms "bravura" and "tour de force" highlight the notion of virtuosity as it pertains to executing the challenging demands of this avant-garde score and speaks to Robison's ability as a performer. Classifying Voice in such a way also serves to prove Brookes' claim from earlier in his review that "for those concertgoers who would rather jump through a plate-glass window than submit to an evening of contemporary music, the works of Tōru Takemitsu usually come as a revelation." 22 With this caveat in mind, Brookes's decision to highlight both the technical demands of Voice and Robison's virtuosic execution of the work attempts to contextualize a compositional language that is demanding on the listener within parameters with which lay audiences can identify; Brookes seems to suggest that-compared to the complexity of comprehending contemporary music_ - perhaps it is easier for lay audiences to recognize that a work is technically challenging or that a performer is particularly virtuosic in their technical facility.

Bernard Holland's review for the New York Times also serves to frame Voice within a justifiable and tangible context based not only on Robison's technical facility as a performer but also Takemitsu's creativity as a composer. Holland's critical language is not as mature as that of Brookes; he declares that in Voice, "the player speaks, grunts, cries and spits invective across the mouthpiece. Tones are made to waver, dip and slide." ${ }^{23}$ While this description suggests the presence of both extended flute techniques and theatrical vocal elements, Holland does not demonstrate the same level of descriptive accuracy of Brookes. However, what Holland does capture is Takemitsu's novel technical demands as realized by Robison. Holland introduces Robison as "a smart, sensitive and well-equipped performer, with muscle when muscle is needed and delicacy enough as well" who also "has taste in programming."24 This introduction establishes Robison as an artist whose opinion the audience should trust, particularly regarding programing; the choice to include Takemitsu on the program is justified because of her "taste," and the audience can trust that the performance sounds as it should, due to her capabilities as a

22 Stephen Brookes, “Tōru Takemitsu, Timelessly Contemporary.”

${ }^{23}$ Bernard Holland, "A Flutist Pushing the Edge to Find a Graceful Resolution,” New York Times, September 18, 2006.

${ }^{24}$ Ibid. 
flutist. Holland later explains that Voice "belongs to a postwar period when composers became as much inventors as musicians" and that it is "an exercise in instrument bending." 25 Describing Takemitsu as an inventor and Voice as an exercise in extending the instrument beyond its conventional capabilities also serves to prove the complexity of the work and marks not only Robison but also Takemitsu as possessing the high level of creative genius and mastery exhibited by a virtuoso.

Whereas reviews of Robison's performances display critically-mature language that promotes the notion of virtuosity, language pertaining to Leonard Garrison's recording of Voice on his album Voices in the Wind highlights his extensive study and demonstrated mastery of the score in an apparent attempt to legitimize the work. Released in September 2014 on Centaur Records, Voices in the Wind is a collection of extended technique literature for solo flute including Ian Clarke's Zoomtube, Gergelty Ittzés' Totem, Robert Aitken's Icicle and Plainsong, Salvatore Sciarrino's Addio case del vento, Stockhausen's Flautina, Saariaho's Couleurs du vent, Robert Dick's Gravity's Ghost, Harvey Sollberger's New Millennium Memo, and Voice. Garrison is Associate Professor of Flute at the University of Idaho, and he was granted a sabbatical leave in fall 2012 to pursue an international study of flute repertoire containing extended techniques. With the exception of Sciarrino, Stockhausen, and Takemitsu, Garrison worked directly with the composers on each of the works recorded on the album. For the works where it was not possible to work with the composer, Garrison turned to other performers who had worked directly with the composer or the performers for whom the works were written; in the case of Voice, he studied with contemporary flutists Robert Dick and Robert Aitken — who had both received coachings from Takemitsu - in order to craft his interpretation.

In the January/February 2015 issue of Fanfare magazine, Colin Clarke reviewed Voices in the Wind and also interviewed Garrison regarding the preparation that went into recording the album. In the interview, Clarke provides a platform for Garrison's ability to speak about these works in such intimate detail. By allowing Garrison's words to reach a wider audience through a written medium, Clarke showcases the performer's musical knowledge and ability to describe the works on the album with mature, accurate, and concise language. In the interview, Garrison

25 Bernard Holland, “A Flutist Pushing the Edge to Find a Graceful Resolution.” 
defines the raison d'etre for Voices in the Wind as an exploration of "the current state of the flute in its variety of increased capabilities" as a result of the explosion of new sounds and timbres for the flute-i.e. extended flute techniques - that began to emerge from collaborations between composers and flutists in the 1950 s. ${ }^{26}$ Clarke admits early in the interview that many of his questions concern the different techniques that each composer uses; in response to this question regarding Voice, Garrison references extended techniques that mimic the flute used in Japanese Noh theater such as forceful air attacks, singing while playing, multiphonics, and the theatrical vocal effects.

As a result of Garrison's explanations of the techniques in the score from a performer perspective, there is no need for Clarke's album review — which immediately follows the printed interview in the publication - to attempt to conjure up specific language to describe these techniques. Rather, the detailed descriptions from the preceding interview allow Clarke to focus on the overall aesthetic experience of Voice. His album review states:

The very first gesture of Takemitsu's Voice, with its vocalization as well as its flute explosions, presages what is to follow. This disc is deliciously uncompromising. Each piece has its own fascinations as well as its own unique demands, demands that Garrison positively feeds off. Yet there is lyricism aplenty here, and Takemitsu's piece seems to ensure that we realize that this is an integral part of the repertoire of the "new flutist." The date of composition of Voice is 1971, and it retains its freshness to discovery even to this day.

Clarke suggests that the theatrical opening of Voice leaves a dramatic impression that aptly prefaces a program of avant-garde flute literature. By citing the "uncompromising" nature of the repertoire and referencing its "fascinations," and "demands," Clarke is able to assert Garrison's command and authority over the works, thus assigning an air of authenticity to the performances.

Ronald Grames also reviewed Voices in the Wind for the January/February 2015 issue of Fanfare, and his choice of language in the introduction to his review also suggests a need to canonize Voice as part of the standard contemporary solo flute repertoire. He begins his review with a blatantly obvious warning label:

\footnotetext{
26 Colin Clarke, "Voices in the Wind: Flutist Leonard Garrison on recording contemporary works," Fanfare, January/February 2015, 146.
} 
A whole disk devoted to contemporary solo flute and piccolo works featuring extended techniques is unlikely to be everyone's cup of tea. However, for listeners who seek out the new and unexpected, I cannot imagine a better introduction to the sound world than this release. ${ }^{27}$

The language in this stipulation implies that there is something problematic or particularly niche market about the collection of works on this disc and that it is only for adventurous listeners. Even if this is true, the recognition of this fact subsequently tasks the remainder of Grames' review with promoting the album, praising Garrison's playing, and validating the works on the album despite the stigma associated with the genre of contemporary classical music. Grames leans heavily on Garrison's calculated approach to learning the works on the album by citing the details of his "sabbatical odyssey," the "impressive and absorbing" results, and the virtuoso status of the collection of works. ${ }^{28}$ By legitimizing Garrison as a scholar and a performer, Grames legitimizes his choice of repertoire by association.

Todd Gorman's review of Voices in the Wind for American Record Guide follows in the same fashion. His review also begins with an explanation of Garrison's extensive sabbatical study, and the short review focuses on the overall experience of the album and Garrison's playing in lieu of a detailed discussion pertaining to each work. Gorman praises Garrison for his tone and flexibility in addition to his execution of the theatrical vocal effects in Voice and Ian Clarke's Zoomtube. However, rather than simply praising Garrison's playing, Gorman includes the following qualifier: "Readers who are skeptical about how much avant-garde flute playing might appeal to them need to discover Ian Clarke, England's analog to Robert Dick, who is also here." 29 This added caveat assumes a skeptical attitude toward avant-garde music and highlights the most approachable composers on the album - Ian Clarke and Robert Dick - which seems to serve as a hook for the rest of the repertoire choices. To conclude the review, Gorman writes, "These committed, commanding performances are well worth hearing, and all the unusual details are captured in very good sound." 30 Once again, this seems to suggest that an informed approach

\footnotetext{
${ }^{27}$ Ronald Grames, Review of Voices in the Wind, Fanfare, January/February 2015, 149.

28 Ibid.

${ }^{29}$ Todd Gorman, Review of Voices in the Wind, American Record Guide, November 2014, 193.

30 Ibid.
} 
and command of the repertoire validate the perceived "unusual" techniques included in this collection of works.

Surprisingly, the review of this album that contains the least descriptive vocabulary is by a fellow flutist; Nicole Riner reviewed Voices in the Wind for the Winter 2015 issue of The Flutist Quarterly and only comments on Garrison's execution of the demanding program. Perhaps the lack of discussion pertaining to the unique technical challenges of these works can be attributed to Riner's assumption that those reading a specialist journal associated with the National Flute Association would be familiar with the repertoire included on the album. Riner claims that the works on this album can all be considered "standard repertoire," commends Garrison's "great mastery over the lexicon of modern extended techniques" and his commitment to the theatrical demands of Voice, and concludes, "He takes no liberties in the specific directions in the score, which I respect; he faithfully executes what the composers have written, then goes beyond the notation to offer up his musical perspective through his interpretations." ${ }^{31}$ Riner's opinion that this album offers a faithful execution of the composers' intentions suggests that it is Garrison's methodical approach to the score that legitimizes the repertoire and not the repertoire itself.

Aside from attempts to validate Voice as part of the standard flute repertoire, increased critical commentary pertaining to the theatrical elements of the work emphasized the overall composite experience of the work in the 21 st century. Reviews in this category are the first in this study to discuss the actual text included in the composition; they also expand the attention given to the Japanese-inspired techniques. Regarding an analysis of the text, several previouslymentioned reviews comment on the suggested presence of an other-worldly spirit in the poetry; Jean Hasse for the Bristol Post calls Voice "haunting;"32 Stephen Brookes for the Washington Post commends Paula Robison's virtuosic display of extended techniques to "create a haunted figure, alone in an internal wilderness of terror and awe;" 33 Leonard Garrison refers to the work as a "ghost story" with perhaps "the most dramatic opening of any flute solo... shocking the

\footnotetext{
31 Nicole Riner, Review of Voices in the Wind, The Flutist Quarterly, Winter 2015, 60.

32 Jean Hasse, "Flautist has an Extensive Repertoire."

33 Stephen Brookes, "Toru Takemitsu, Timelessly Contemporary.”
} 
listener to attention;" 34 and Ronald Grames explains that the work "uses a wide variety of special techniques to add to its eeriness, and features the soloist declaiming, at times through the flute, a short ghostly poem in French and English." 35 The vocabulary from these excerpts recognizes the meaning of the text in a way that had been previously unexplored in critical reviews of Voice. Commentary on this blatantly-programmatic element of the composition draws attention to the overall audience experience of the work in a way that joins Takemitsu's colorful extended technique language with the theatrical vocal elements.

A few reviews also regarded the Japanese-inspired extended techniques as a vehicle for creating a theatrical experience. Penny Thow for The Mercury interviewed flutist Emily Beynon in advance of a "Musica Viva" series concert on May 11, 2007 that featured repertoire loosely inspired by the human voice including Poulenc's Sonata for flute and piano, Samuel Barber's Melodies Passageres, Schubert's Introduction and Variations on “Trockne Blumen," Jolivet's Chant de Linos, and Voice. Regarding Voice, Beynon references the theatrical vocal effects of "singing, whispering, and speaking" in addition to "very shakuhachi-inspired attacks and key clicking, which is almost like pizzicato on the violin" resulting in "quite an experience both to play and to listen to." 36 Similarly, a review in the New Zealand Herald of the Karlheinz Company's concert at Auckland University in May 2009 references the traditional Japanese music elements in Voice. The unnamed reviewer states, "Here was a piece drawing on and fusing so many cultural diversities, from the tremor of Japanese shakuhachi and elements of Noh theatre to an array of expressive techniques familiar in contemporary Western music" and the effect of this fusion "swept one out of the here and now." ${ }^{37}$ Both of these reviews effectively frame the shakuhachi and Noh theatre inspired elements realized through Western extended instrumental techniques as they contributed to the overall theatrical experience of the composition.

\footnotetext{
34 Colin Clarke, "Voices in the Wind: Flutist Leonard Garrison on recording contemporary works."

35 Ronald Grames, Review of Voices in the Wind.

36 Penny Thow, "Voice Interpreted," The Mercury, May 10, 2007.

37 The New Zealand Herald, “Karlheinz Company at Auckland University Music Theatre," The New Zealand Herald, May 20, 2009.
} 
In retrospect, Alan Blythe for The Times appears to have predicted one of the most important elements of critical language development pertaining to Voice in his preview of the allTakemitsu concert at the Roundhouse in London on May 6, 1973: the constantly-evolving role of communication in the reception of contemporary music. Blythe gleaned from his interview with Takemitsu that the composer's music - which reconciles Eastern and Western musical influences in order to present a uniquely synthesized style — attempts to "superimpose on both [influences] his own view that what matters, above the calls of country and background, is communication between people - between composers and their interpreters, between both of these and the public." 38 The communication of Voice through both performance and language has relied on the evolution of interactions between Takemitsu, performers of his works, and the public.

Constructing a reception history narrative of Voice reveals a clear and linear developmental arc of critical language used to describe the work including negligible mentions of the work in the 1970s, recognition of the theatrical elements of the work within negative criticism in the 1980s, descriptions of Japanese-inspired extended techniques as communicated through a Western instrument in the 1990s, and the emergence of a mature critical vocabulary coupled with notions of virtuosity and specialism in contemporary music performance in the 21 st century. While critical language used to describe Voice still comes with caveats, the trends in the critical language of the past 45 years reveal a shift in perception regarding Voice from a complex, incomprehensible, and stigmatic avant-garde work to a technically-demanding tour-de-force showpiece for the modern flutist.

38 Alan Blyth, “East and West at the Round House," The Times, May 5, 1973. 


\section{Chapter 4: Karlheinz Stockhausen Flautina (1989) Reception History}

\section{Flautina Introduction}

When considering the scope and diversity of the avant-garde movement in music, the many ways in which music can be considered "experimental" become abundantly clear; previous chapters in this study illuminate different permutations of innovation in contemporary music including experimental approaches to timbre and experimental fusion of international styles and influences. Among composers of experimental electronic music, Karlheinz Stockhausen (1928-2007) was undoubtedly an influential and pioneering figure, but his innovative approach to serialism — serializing parameters beyond pitch including rhythm, intensity, duration, timbre, and spatialization - and his work with aleatory were also historically significant and groundbreaking. Flutists are fortunate to have a wealth of solo repertoire by Stockhausenconsidering his status as arguably the most important German figure of the avant-garde—and this is largely thanks to one of his most-trusted colleagues.

An increasingly-popular trend in the creation and promotion of contemporary classical music that has continued to the present day is the collaboration between composers and specific trusted performers. Tōru Takemitsu sustained a long collaborative relationship with flutist Aurèle Nicolet, and Stockhausen worked closely with Dutch flutist Kathinka Pasveer from the 1970s until the composer's death. Pasveer continues to promote Stockhausen's works and maintains his legacy by running the sound projection for live performances of those of his works that include electronics, teaching courses on the interpretation of his works, and serving as the director of the Stockhausen Foundation for Music. The sustained collaboration between Stockhausen and Pasveer over a series of decades produced a number of flute works, including sanctioned transcriptions and solo works derived from portions of his operas. The solo works originally for other instruments with a composer-sanctioned flute version include In Freundschaft (1977), Amour (1981), Xi (1986), and Ypsilon (1989). The independent solo works derived from portions of the Licht cycle include Piccolo (1977) for piccolo from Dienstag aus Licht; Zungenspitzentanz (1983) for piccolo and Kathinka's Gesang (1983) for flute and electronics from Samstag aus Licht; Susani's Echo (1985) for alto flute, Entführung (1986) for piccolo, and Flautina (1989) for 
flute, piccolo, and alto flute from Montag aus Licht; and Freia (1991/2) from the opera Freitag aus Licht.

What is overwhelmingly clear from this list of compositions is the influence of material from Stockhausen's opera cycle Licht on subsequent independent solo works for flute. Undoubtedly his largest and most ambitious undertaking, Licht is a seven-part cycle with individual operas corresponding to different days of the week; composed between 1977 and 2003, the operas include Donnerstag (1981), Samstag (1984), Montag (1988), Dienstag (1993), Freitag (1996), Mittwoch (1998), and Sonntag (2003). Stockhausen composed the non-vocal parts of Licht for his small circle of trusted collaborators including his sons Markus (trumpet) and Simon (keyboard) in addition to Suzanne Stephens (basset horn) and Kathinka Pasveer (flute). Licht breaks from conventional operatic story-telling in that it relies on not only singers but also instrumentalists and dancers/mimes to carry the narrative; the instrumentalists for whom Stockhausen composed parts of Licht appeared on stage in costume and served as crucial parts of the operas.

One of the solo flute works derived from the Licht cycle is Flautina (1989) for piccolo, flute, and alto flute, all played by a single performer. Stockhausen composed Flautina as a birthday present for Pasveer. It is an independent work, not an excerpt from Montag, although Stockhausen drew the harmonic material of the composition from the Eve-formula: the motivic twelve-tone row in Montag that represents the character Eve; Stockhausen subsequently spread the twelve pitches out over the combined range of the piccolo, flute, and alto flute. According to Stockhausen's notes in the score, the character Flautina is "a flute-spirit in a human costume: bewitchingly enchanting." "The extended flute techniques in the piece include microtones, glissandi, flageolett (whistle tones), key clicks, flutter tonguing, singing while playing, "toneless rushing" (residual or "aeolian" sounds), tongue clicks, kissing noises, and "irregular spitting" ("pizzicato" articulation). As the performer changes between instruments, Stockhausen creates a sound bridge with sung and hummed notes which he refers to as "colored pauses."

Stockhausen also provides strict performance practice notes regarding the theatrical components of Flautina. He states that the work should be performed from memory and that the

\footnotetext{
${ }^{1}$ Karlheinz Stockhausen, Preface to Flautina (Kürten: Stockhausen-Verlag, 1995).
} 
performer must wear a special item: a silver quiver with three different sized tubes for the purposes of holding the three necessary instruments for the piece. He specifies the diameter and length of each tube and explains that the "quiver is worn at the waist, hung on a belt. Seen by the player, the piccolo is to the left of the central body axis; next to it, further to the left is the flute, and still further to the left, is the alto flute."2 Regarding lighting, he provides explicit instructions on the positions and sequencing of various spotlights, how the performer is to enter the spotlight, and how the lights should signal bows at the conclusion of the performance. Finally, he explains that a clip-on microphone should be worn by the performer and that a sound projectionist at a mixing console should control the volume of the amplification. Such specific instructions regarding costuming, lighting, and amplification in addition to strict musical notation set Flautina apart from the majority of the contemporary flute repertoire.

The decision to include Flautina in this study was a combination of Stockhausen's prominence as an avant-garde composer, his large collection of flute compositions as a result of his relationship with Pasveer, and the extraordinarily detailed theatrical specification in the score. However, since this document only examines sources in English, constructing a clear and linear reception history of this work proves to be challenging - much of the scholarship and criticism pertaining to Stockhausen's works are in German and thus lie outside the scope of this study. This chapter attempts to analyze general trends presented by the limited literature included in this study but unfortunately, this analysis relies on conclusions from previous chapters as a framework rather than presenting an independent narrative thread. However, despite the lack of a continuous narrative arc, a few prominent trends emerge in the English critical language used to describe Flautina including the interplay of music and theater, the importance of Stockhausen specialists, and the approachability of the work despite an apparent lack of widespread familiarity.

\section{The 1990s}

Pasveer premiered Flautina at the opening of the Wien Modern festival on October 29, 1989 in Mozart Hall at the Vienna Konzerthaus. Two newspaper reviews from the Stockhausen

\footnotetext{
2 Karlheinz Stockhausen, Preface to Flautina.
} 
archives reveal criticism concerning the premiere of Flautina-however, they are entirely in German and thus do not fall within the language restrictions of this study. While Germanlanguage reviews of the premiere will not be considered for this project, future research regarding the reception history of Flautina warrants an expansion of the language parameters to include these two articles from the Stockhausen archives: "Holzpfade und Kontra-Punkte Die Bewegungen der Avantgarde” by Wolfgang Fuhrmann ${ }^{3}$ and “'Wien Modern' mit Hauptkomponisten eröffnet Erlesenes stand am Beginn” by E. Jachimowicz. ${ }^{4}$

The closest thing to an English-language critical review of the premiere of Flautina is a review of an early performance (not the premiere) of Montag aus Licht - the opera from which Stockhausen derived the solo flute work — at the Holland Festival in 1988. Pasveer performed the role of the Pied Piper in Act III, Scene II of Montag, but there is no evidence to suggest that the boyish Pied Piper character is related to the feminine flute-spirit Flautina in any way. Montag premiered on May 7, 1988 at the Teatro alla Scala in Milan, Italy; one month later, Richard Barrett attended a performance of the opera at the Concertgebouw in Amsterdam as part of the 1988 Holland Festival, and it was this later performance that he reviewed for the journal Tempo. While this review does not directly concern Flautina, it is included in this study because it addresses Stockhausen's aesthetic, Pasveer as a performer, and the experience of the work from which Flautina was derived.

Regarding Stockhausen's penchant for shocking theatrical elements - the set of Montag features a large naked statue of a woman from whose womb various characters enter the stageBarrett remarks, "this type of presentation, however well-prepared and well-performed on the musical side (which as always it was, quite astonishingly so), has an air of the amateur theatricals about it, which the performers' obvious total commitment seemed curiously to intensify."5

Barrett lauds the performers for their dedication and commendable execution of the music, but

\footnotetext{
${ }^{3}$ William Fuhrmann, "Holzpfade und Kontra-Punkte Die Bewegungen der Avantgarde,” Der Standard, October 31/November 1, 1989.

${ }^{4}$ E. Jachimowicz, “'Wien Modern' mit Hauptkomponisten eröffnet Erlesenes stand am Beginn,” Kurier, date unknown. Scanned article PDF received via e-mail from the Stockhausen archives.

5 Richard Barrett, “"Montag Aus LICHT' at the Holland Festival,” Tempo, no. 166 (September 1988): 4345. http://www.jstor.org/stable/945909.
} 
he simultaneously insinuates a lack of professionalism on the part of Stockhausen due to his theatrical choices. Regarding Pasveer's performance as the Pied Piper, Barrett states "the piccolo music particularly has a sparkling and intricate virtuosity which single-handedly sustains this otherwise overlong and predictable procession."6 Barrett suggests that Pasveer's virtuosity as an instrumentalist was enough to sustain a scene that he perceived to be too long, and the referenced piccolo music eventually became the independent solo piccolo work Entführung. Barrett concludes that the music in Montag, "while hardly ever less than fascinating, and frequently mesmerizing, is embarrassingly let down by the puerile and insulting dramaturgy." ${ }^{77}$ While the theatrical specifications of Flautina are seemingly unrelated to the extreme presentations of the female body in Montag, Barrett's negative criticism of the interaction between music and theater provides a reference point regarding critical views of Stockhausen's overall aesthetic_-Barrett's commentary is a vehicle for comparative analysis regarding not only subsequent reviews of Flautina that address the same interaction of music and theater but also the overtly negative critical reviews of Vox Balaenae and Voice from the 1980s as analyzed in chapters two and three of this study.

A marked drop off in documented performances of avant-garde flute works in the 1990s as seen in previously-examined case studies also contributes to the difficulty in constructing the early years of Flautina's reception history. With the exception of the late 1980s review of Montag, this study only revealed two pieces of English-language critical commentary regarding Flautina in the 1990s. The first is an album review of the two-CD Stockhausen Edition 28 set Music for flute, piccolo flute, alto flute recorded by Kathinka Pasveer and released in 1993. Nicholas Hodges reviewed the two-disc set—which includes In Freundschaft, Piccolo, Amour, Susanis Echo, Xi, Zungenspitzentanz, Flautina, Ypsilon, and Kathinkas Gesang-for the March 1993 issue of the Musical Times. Regarding this collection of flute works recorded by the foremost authority on Stockhausen's flute music, Hodges writes:

Many of the flute pieces recorded by Kathinka Pasveer manipulate overly simple material almost autocratically, but justify themselves by the strangeness of their logic or scale

\footnotetext{
${ }^{6}$ Richard Barrett, “'Montag Aus LICHT' at the Holland Festival.”

${ }^{7}$ Ibid.
} 
(temporal in the half-hour Kathinkas Gesang and the tangibly quaver $=7.5 \mathrm{Xi}$, and acoustic in Ypsilon, whose melodic complexities all occur microtonally within a minor third, accompanied by Indian bells). The other pieces on this disc are simple and inarticulate padding out of time. Thankfully, in Stockhausen's output this is the exception rather than the rule. ${ }^{8}$

In lieu of addressing Flautina directly, Hodges lumps it into a category of pieces on the album that he felt were merely a "simple and inarticulate padding out of time." However, considering the integral nature of Stockhausen's meticulously-specified performance instructions for Flautina, it is not shocking that a work so dependent on the visual components of costuming, lighting, amplification, and memorization would not appear to translate well to the audio-only format of a recorded album. On an audio-only recording, the purely-musical elements of Flautina do in fact manipulate "overly simple material"-Stockhausen spreads the twelve-tone Eve formula from Montag over the composite range of the piccolo, flute, and alto flute and temporally lengthens the formula four-fold. ${ }^{9}$ Hodges' criticism thus indirectly comments on the necessity of the combined musical and theatrical elements of Flautina by dismissing the musical elements when presented as an independent entity.

Fortunately, the other piece of critical commentary regarding Flautina in the 1990s is a concert review that is able to take the musical and theatrical components of the work into equal consideration. Daniel Cariaga for the Los Angeles Times reviewed a flute recital by Dorothy Stone presented on September 29, 1996 as part of the Southwest Chamber Music Society "Soliloquy" series at Armory Center for the Arts in Old Town Pasadena, CA. The allStockhausen program included Susani's Echo for alto flute, Entführung for piccolo, and Flautina along with two unnamed works - Cariaga states that there were five works on the program but only provides titles for three. Cariaga also claims that this performance served as the United States premiere of all but one of the works on the program; he does not specify which work had previously been performed in the United States, and Dorothy Stone's passing in 2008 prevents

\footnotetext{
${ }^{8}$ Nicolas Hodges, Review of Flute Music: In Freundschaft, Piccolo, Amour, Susanis Echo, Xi, Zungenspitzentanz, Flautina, Ypsilon, Kathinkas Gesang, The Musical Times Vol. 134, No. 1801 (March 1993$)$ : 155. http://www.jstor.org/stable/1193872.

${ }^{9}$ Karlheinz Stockhausen. Preface to Flautina.
} 
consultation with the performer on this matter. Thus, this performance might have been the United States premiere of Flautina, but this is impossible to confirm from this review alone.

Regarding the theatrical elements of the work, Cariaga notes that the performer wore a "flute quiver," but does not comment on the movement of the performer, memorization, or lighting. He attributes his description of the extended flute techniques in the work to the program notes and cites "kissing noises ... key slapping, tongue clicks, sighing, spitting noises, voiceless whistling ... wind tremolos, key clatter and whispered numbers." 10 Cariaga refers to the program notes as "Stockhausen's program notes," thus making it unclear whether he is referencing notes in the program from the recital or the performance notes in the preface to the score. However, it is likely that Cariaga had access to the score because his description of the character Flautina as "a flute spirit in human costume" is a verbatim quotation from Stockhausen's prefatory notes. If Cariaga did in fact have access to the score for Flautina, his decision to use the composer's verbiage rather than his own attempted descriptions of the extended techniques in the work suggests a recognition of the composer's ability to communicate in an accurate and musically-mature language.

If the September 29, 1996 performance of Flautina in California was indeed the U.S. premiere of the work, this would explain the lack of American criticism in the first decade of the work's existence. The late 1980s/early 1990s reviews of Montag at the Holland Festival and Kathinka Pasveer's two-album set of Stockhausen's flute works seem to echo the overt negative criticism of the 1980s demonstrated in the previously-explored works Vox Balaenae (Chapter 2) and Voice (Chapter 3), but these early Flautina-related reviews also serve to illuminate the importance of the interaction of music and theater in Stockhausen's works - whereas Barrett felt that the juvenile and disrespectful dramaturgy of Montag detracted from the music, Hodges felt that the music of Flautina could not stand alone without the visual theatrical components as specified by Stockhausen in the score. Regarding the language used to describe the extended flute techniques in Flautina, Cariaga uses mature and accurate descriptive vocabulary, yet it is presented in quotation and most likely drawn directly from the composer. However, what these 1996.

\footnotetext{
${ }^{10}$ Daniel Cariaga, “Solo Flutist Stone Intrigues With Stockhausen Works,” Los Angeles Times, October 1,
} 
early sources make abundantly clear — even though they are few in number - is that Flautina, like many of Stockhausen's works, relies on a balanced interplay of music and theater.

\section{The 21st Century}

Documented performances of Flautina marginally increased in the 21 st century, but based on the limited amount of English-language criticism, it appears that this work has remained, considering the renown of the composer, a remarkably under-performed work of the contemporary flute repertoire. In addition to the paucity of source material, the language used to describe Flautina in these limited reviews also suggests a wide-spread unfamiliarity with the work-reviews in the 21 st century continue to almost entirely focus on describing background information on the work, the extended technique vocabulary, and Stockhausen's specified theatrical components rather than dedicating a portion of the review to commentary on the composite aesthetic experience. While the descriptive language used to identify and discuss the extended flute techniques in Flautina includes mature and accurate musical terminology, the detailed explanations regarding the content of the work in these reviews suggests an assumed lack of familiarity with the piece. However, despite this apparent unfamiliarity, the criticism of the 21 st century largely regards the work as an approachable and charming gem of the avantgarde even though Stockhausen's theatrical specifications in Flautina are among some of the most strict and striking of the flute repertoire; this is likely due to performances of the work by flutists who are intimately acquainted with the works of Stockhausen.

The Montreal Stockhausen Project presented the first documented performance of Flautina in the 21 st century in November 2008 at the Enwave Theatre in Toronto as part of the "New Music Concerts" series, founded by contemporary flutist Robert Aitken. The concert was arranged as a tribute to Stockhausen, who had passed away one year prior, and many of the musicians on the program had worked directly with the composer, including the flutist who performed Flautina: Lise Daoust. With the exception of Gesang der Jünglinge, the program consisted entirely of works derived from the Licht opera cycle, including Ave for alto flute and basset horn, Entführung for piccolo, Kathinka's Gesang for flute, and Flautina. The two pieces of criticism that address this performance are Jessica Lombardi's review for The Live Music 
Report and Stanley Fefferman's review for Showtimemagazine.ca. Lombardi's review describes the instrumentation of Flautina, the costuming necessary for switching between the three instruments, and how these instrument changes are sonically bridged by the flutist. Regarding extended techniques, Lombardi does not reference any of the flute-specific techniques such as microtones, glissandi, whistle tones, key clicks, or flutter tonguing, but rather only discusses the vocal effects and various mouth noises as they pertain to bridging the changes between instruments: "Wearing a belt that held the three instruments to her side, [Lise Daoust] skillfully alternated between instruments, and each time concealed the silences with musical hums and hahs, in the form of tongue clicks, sighing, whistling, and making kissing and spitting noises."11 Lombardi regards Daoust's performance as "skillful" and later regards the overall performance of the work as "an impressive sight and sound to reflect on," 12 thus highlighting the required technique and theatricality of the performer within the framework of a comprehensible work.

Stanley Fefferman's review for Showtimemagazine.ca also comments on the multiple instruments and costume required for Flautina, but he additionally includes details regarding the extended flute techniques used in the work and the interplay of music and theater. Regarding the extended flute and voice techniques used in the work, Fefferman explains:

The changes between instruments were bridged by sung and hummed notes. Daoust elicits the 'coloured rests' by making rushing noises, kissing noises above the mouth-hole with key-slapping, tongue-clicks and sighing, flutter- tongued rushing noises alternating with irregular staccato spitting noises and voiceless whistling. ${ }^{13}$

Some of the terminology used in this description suggests either access to the score, a conversation with the performer, or an intimate personal knowledge of the work. The phrase "coloured rests" is curiously close to "colored pauses"- the terminology used by Stockhausen in the preface to the score to describe the sonic bridge created by the vocal techniques while the performer switches instruments. While the list of flute and voice techniques is mature and

\footnotetext{
11 Jessica Lombardi, “The Montreal Stockhausen Project,” The Live Music Report, November 15, 2008. http://www.thelivemusicreport.com/2008/November/StockhausenProject_nov08.html

12 Ibid.

13 Stanley Fefferman, “Montreal Stockhausen Project@ New Music Concerts,” Showtimemagazine.ca, November 16, 2008. http://www.showtimemagazine.ca/?p=236.
} 
accurately descriptive, "rushing noises," "kissing noises," "tongue clicks," and "irregular spitting" are also exact verbiage from Stockhausen's performance notes. Citation of Stockhausen's preface to the score might constitute good scholarship in a more academic setting, but the heavy use of quotation in a concert review could be perceived as a lack of vocabulary or integrity on the part of the reviewer-this approach merely demonstrates the reviewer's ability to cite the composer's words rather than demonstrating the reviewer's personal vocabulary of mature critical language. Fefferman's review goes a step beyond that of Lombardi in that it provides more substantial commentary on the composite experience of the musical and theatrical elements; he states, "The overall effect, beyond the obvious virtuosity, is of great purity and a sense of freedom, as if Debussy's 'faun' had escaped from his afternoon haunting ground into a more open story." 14 The use of the words "virtuosity," "purity," and "freedom" in conjunction with a reference to Debussy's enchanting, colorful, and rhapsodic Prélude à l'après-midi d'un faune presents Flautina as an approachable and non-complex product of the avant-garde and frames the aesthetic experience of the work with a reference to arguably the most well-known flute solo of the orchestral repertoire.

In addition to emphasis on the approachability of Flautina and the interplay of music and theater, the importance of performers intimately acquainted with the works of Stockhausen emerged as a prominent narrative thread in the 21 st century; one of the central figures in the reception history of this work is flutist Leonard Garrison. Not only does his album Voices in the Wind (introduced in Chapter 3) contain a recording of Flautina, but he discussed the work in an interview for Fanfare magazine and authored a review of the work for the National Flute Association Convention Chronicles, thus demonstrating his intimacy with the piece through multiple outlets. As a critic, Garrison reviewed a joint performance by flutists Carol Wincenc and Christina Jennings at the 2011 National Flute Association Convention in Charlotte, NC. Wincenc's contributions to the program included two works by Joan Tower: For Marianne for solo flute and Rising for flute and string quartet; Jennings' contributions included Taffanel's Fantasie on Françoise di Rimini and Flautina; and the performers joined forces for Christopher Caliendo's Hoedown for two flutes. Garrison describes the instrumentation and costuming

\footnotetext{
14 Stanley Fefferman, “Montreal Stockhausen Project @ New Music Concerts.”
} 
required for Flautina, and, regarding both the extended techniques in the work and Jennings' performance, he writes, "The score calls for the flutist to sing during instrument changes and features a whole gamut of extended techniques from air sounds and timbral trills to flutter tonguing. Jennings met the challenge with aplomb." 15 Considering the intended flute-specialist audience for this review, Garrison assumes that reference to a "gamut of extended techniques" followed by a small list of examples is sufficient for a readership consisting of flutists. However, "gamut" also implies a full range of extended techniques, and Garrison commends Jennings for demonstrating a confident command over the vast catalogue of musical and theatrical demands.

Another review by a flutist and intended for flutists is Nicole Riner's review of Voices in the Wind for The Flutist Quarterly. This source was previously examined in reference to Garrison's performance of Takemitsu's Voice; as discussed in Chapter 3, Riner only comments on Garrison's execution of the challenging repertoire on the album with no discussion dedicated to the unique technical demands of each work. Her claim that most of the works on the album can be considered "standard repertoire" implies that those reading a flute journal should be familiar with this collection of repertoire. Riner offers one small passing comment on Flautina —_Pieces like Kaija Saariaho's Couleurs du vent and Stockhausen's Flautina show Garrison's lyrical skill on alto flute and piccolo"16_ but this mention merely comments on the use of multiple instruments and Garrison's demonstrated proficiency on the alto flute and piccolo.

Fortunately, album reviews and interviews from the January/February 2015 issue of Fanfare magazine provide a more substantial foundation on which to base an analysis of the critical language used to describe Flautina even though they reference an audio-only version of the work. Like Riner's album review, Ronald Grames and Colin Clarke's reviews of Voices in the Wind were also previously cited in Chapter 3 for their discussion of Takemitsu's Voice. Regarding Garrion's recording of Flautina on Voices in the Wind, Grames' review states, “Karlheinz Stockhausen’s witty Flautina (1989), taken from the pied piper scenes of his opera

\footnotetext{
15 Leonard Garrison, "Jennings and Wincenc in Concert," The National Flute Association Convention Chronicles, August 2011. http://www.nfaonline.org/Annual-Convention/Convention-Chronicles/ Convention-Chronicle.aspx?ChronicleID $=142$.

16 Nicole Riner, Review of Voices in the Wind.
} 
Montag aus Licht, has many of the qualities of his electronic scores, played (and vocalized) in real time on flute, alto flute, and piccolo."17 Though this scant mention of the work mostly provides information on instrumentation and the source of the work, Grames' describes Flautina as "witty" which suggests a perceived air of intelligence and humor and removes the complex and pretentious stigma of contemporary classical music from the work.

Colin Clarke's interview with Garrison and subsequent review of Voices in the Wind provides more detailed and substantial critical commentary than Grames' review. Clarke's review recognizes the difficulty in translating a work that is so dependent on the interplay of music and visual theatrical components to an audio-only recorded medium, yet he claims, "Obviously, on disc we miss out on the costume and staging, but the dramatic basis of the piece still comes across in Garrison's performance." 18 It is unclear what Clarke perceived the "dramatic basis" of the piece to be-perhaps the enchanting nature of the flute spirit character Flautina or the continuity of the music through the "colored pauses"- but recognition of this drama seems to assert the interdependent relationship between the musical and theatrical elements of the work. Clarke asks Garrison to specify the missing theatrical components of the work that do not translate to a recording, and he explains:

The performer is a 'flute spirit.' One must memorize the piece and move around the stage according to the score, wearing a costume and holding the flute, piccolo, and alto flute in a quiver. I spent many hours building my flute 'quiver' out of painted PVC pipe. During the instrument changes, the performers sings or whistles. ${ }^{19}$

Reference to memorization, prescribed movement, and the required costume provides perhaps the most accurate description of Flautina's theatrical elements in the entire pool of 21 st century criticism. By allowing Garrison to explain Stockhausen's performance specifications, Clarke highlights the importance of the performer's expertise in the realization of Stockhausen's score.

Also contributing to the focus on the flutist's ability to communicate Stockhausen's score through both performance and language is Garrison's opportunity to study Flautina with

\footnotetext{
${ }^{17}$ Ronald Grames, Review of Voices in the Wind.

${ }^{18}$ Colin Clarke, "Voices in the Wind: Flutist Leonard Garrison on recording contemporary works." ${ }^{19}$ Ibid.
} 
Kathinka Pasveer - the flutist for whom Stockhausen composed the work. Garrison explains that he "worked with Kathinka on the piece, and she was patient but exacting, as the score is extremely precise and detailed. One must play at exactly the printed tempos, and tempo changes are specifically notated." ${ }^{20}$ Garrison's reference to the detailed score and Pasveer's exacting demands elevate his interpretation to a level of specialism akin to flutists who had worked directly with Stockhausen on Flautina.

Clarke's album review of Voices in the Wind follows the interview with Garrison and concludes, "If Stockhausen's Flautina emerges for this listener as the gem of the disc, that is probably because of my self-admitted bias towards his music. The composer's never-ending search for truth seems to shine from every note in this virtuosic performance. ${ }^{21}$ Citing virtuosity highlights Garrison's command over Stockhausen's technically-demanding and strict performance specifications, but simultaneously labeling Flautina as a "gem" presents the work as an approachable and charming work of the contemporary flute repertoire despite the complexity of the score.

An example of critical language used to describe Flautina that perhaps best summarizes the trends of the 21 st century is a preview of a "Karamel Classics" concert - a contemporary classical music night at the Karamel Club in London-by multi-instrumentalist, arranger, and composer Amy May. Her online preview of this performance provides details on the scheduled program including Takemitsu's Toward the Sea for flute and guitar; Dai Fujikura's Poison Mushroom for flute and electronics; Rory Simmons' Glass Dancers for string quartet, drums, and electronics; and Flautina. May's notes on Flautina are as follows:

Flautina is supposed to be a 'flute-spirit in human form', and the performer is meant to portray a feminine and enchanting character. It was written as a birthday present for Stockhausen's muse Kathinka Pasveer. The required prop for this piece is a quiver in which the performer places her piccolo, flute and alto flute. When the flautist changes instruments the music is bridged by sung and hummed phrases, the idea being that there

\footnotetext{
${ }^{20}$ Colin Clarke, "Voices in the Wind: Flutist Leonard Garrison on recording contemporary works." ${ }^{21}$ Ibid.
} 
is no lull in the momentum of the music. The piece is quite a private and personal journey, but it still invites the audience in to partake in Flautina's world. ${ }^{22}$

May's description of Flautina summarizes the most commonly addressed topics of 21 st-century criticism pertaining to the work including instrumentation, costuming, the interplay of flute techniques and voice techniques, and information about the character Flautina. While this article is admittedly a preview of a performance and not a concert review, the attention to details unrelated to the composite experience of the work perpetuates an assumed unfamiliarity with the composition. However, despite this assumed unfamiliarity, May describes Flautina as "feminine and enchanting" and "a private and personal journey" while suggesting that the work creates its own "world" of an experience in which the audience can partake, thus presenting the experience of the work as approachable and comprehensible.

While the limited availability of English-language source material presents difficulties in constructing a clear linear narrative regarding the reception history of Flautina, the trends that emerge from the criticism included in this study provide insight into the role of temporality as it relates to the developmental arc of critical language used to describe contemporary flute works. The relative newness of the work as compared to works from the early 1970s and the drop off in documented performances of avant-garde flute works in the 1990s have both seemingly contributed to an assumed unfamiliarity with Flautina, but this observation is not meant to relegate the work to a category of lesser-known compositions. Rather, the critical language pertaining to the work that has emerged proves a maturation of vocabulary over the general passage of time rather than this linguistic development corresponding to the amount of time a composition has existed or the audience's level of familiarity with a composition. The language used to describe Flautina largely regards the work as charming and comprehensible rather than grappling for language to describe the unique extended flute and voice techniques or negatively criticizing Stockhausen's precise theatrical specifications. Through an examination of the interplay of music and theater, the importance of Stockhausen specialists, and the approachability of the work despite an apparent lack of widespread familiarity, critical language

\footnotetext{
22 Amy May, "First Caramel Classics Night," About Amy May. http://www.aboutamymay.com/news/firstkaramel-classics-night [accessed April 2, 2016].
} 
used to describe Flautina demonstrates an increased ability to discuss music of the avant-garde in the 21 st century. 


\section{Chapter 5: Marcos Balter Descent from Parnassus (2012) Reception History}

\section{Descent from Parnassus Introduction:}

Over the past 45 years, a canon of extended flute techniques has gradually developed so that certain techniques may now be considered "standard;" these techniques include harmonics, multiphonics, key clicks, timbral trills, glissandi, whistle tones, singing while playing, fluttertonguing, residual or "aeolian" sounds, and an array of percussive articulations. Though these techniques have remained in constant demand, it has become an increasingly popular practice to continue to extend these central techniques through ongoing modification. The compositional language of extended techniques has become more inventive and widely-varied in the 21st century, and the music of Marcos Balter exemplifies this path of exploration. Balter (b.1974) is a Brazilian-born composer based in Chicago whose energy and experimental creativity permeate his compositional output, and living amidst the thriving Chicago new music scene has afforded him access to some of the greatest contemporary performers of our generation. His music thrives on this adaptation and synthesis of pre-existing techniques to create a novel sound world driven by texture and timbre, and his early exposure to the works of Luciano Berio (1925-2003), György Ligeti (1923-2006), and Steve Reich (b. 1936) combined with his curiosity about music notation, have undoubtedly shaped the aesthetic of his works.

One of Balter's most trusted collaborators is flutist Claire Chase: the founder of the International Contemporary Ensemble (ICE), a MacArthur fellow, and a new music champion. Chase and ICE have played a significant role in the promotion of Balter's work; archived ICE programs from the past five years reveal documented performances of his Pessoa for six bass flutes; ... and also a fountain for solo bassoon and hand percussion; Strohbass for bass flute and baritone saxophone; Alone for solo flute; Cardinal for baritone saxophone and electronics; Raw Item for oboe, cello, percussion, harp, and piano; Landscape of Fear for trumpet and saxophone; Codex Seraphinianus for flute, bassoon, saxophone, and viola; memória for solo cello; Wicker Park for solo saxophone; Aesopica for ensemble and narrator; Ligāre for six players; Edgewater for alto flute and bass flute; Passará for ensemble and electronics; Frisson for flute and orchestra; $\dot{A}$ vis for clarinet and violin; and Descent from Parnassus for solo flute. 
From this list of works, Descent from Parnassus (2012) for amplified solo flute emerges as a crucial contribution to this study. The Art Institute of Chicago commissioned Balter and Chase to create a musical response to a work of their choice from their recently-opened Modern Wing. Balter visited the museum before Chase, and he was drawn to Cy Twombly's The First Part of the Return from Parnassus (1961). ${ }^{1}$ Regarding his return to the museum with Chase, he explains:

I purposefully didn't mention the Twombly right away; this was a collaborative endeavor, and I wanted Claire to have an unbiased and as strong of a connection with the chosen work as I did. So, we decided to visit the Institute together and let the works speak to us. To my surprise, Claire literally froze in front of that very painting and said "This is it!"2

Balter's concern for Chase's connection to the work of art on which the composition would be based demonstrates the increased importance of performers in the creation of contemporary music. The emerging role of the performer as co-creator and the practice of composing works with specific performers in mind are explored in previous chapters of this study through the relationships of both Tōru Takemitsu and Aurèle Nicolet (Chapter 2) and Karlheinz Stockhausen and Kathinka Pasveer (Chapter 3), and the relationship between Balter and Chase has continued this trending collaborative trajectory in the 21 st century.

The importance of performer feedback in the compositional process arises in a $\mathrm{New}$ Music Box spotlight article on Balter. Molly Sheridan asked Balter about his reliance on performer feedback, and he responded with an anecdote regarding the creation of Descent from Parnassus. Balter recounts that after sending the first sketch of the work to Chase, "She called me back, and she said, 'That's not it.' And I was deeply offended! I was mad at her. I'm the composer; you shall not tell me if it is or it isn't_-I'll know!'”3 However, after some time to reflect, he recalls thinking, "She's absolutely right. This is not in any shape or form what this

\footnotetext{
${ }^{1}$ A photo of the painting as well as additional information about the work can be found via the Art Institute of Chicago website: http://www.artic.edu/aic/collections/artwork/186049.

2 International Contemporary Ensemble, “A posthumous homage," International Contemporary Ensemble Blog, January 16, 2012. http://iceorg.org/index.php/blog/post/a-posthumous-homage.

${ }^{3}$ Molly Sheridan, "Marcos Balter: Hyperactive Unity," New Music Box, April 17, 2013. http:// www.newmusicbox.org/articles/marcos-balter-hyperactive-unity/.
} 
painting is about." ${ }^{4}$ He subsequently revised his approach and within 72 hours, he had completed Descent from Parnassus. The details of this interaction demonstrate the increasingly important role that performers play as co-creators of contemporary music in the 21 st century, and Balter's decision to consider Chase's opinions as equal to his own demonstrates an evolution in the ways in which composers and performers interact in order to communicate contemporary music through both performance and language.

Descent from Parnassus for solo amplified flute places equal demands on the performer as both a flutist and a singer/performing artist. The extended flute techniques in the work transcend the modern vocabulary associated with the standard canon of techniques because Balter combines them in unprecedented ways. Balter's compositional language suggests traces of key clicks, percussive articulation, harmonics, residual or "aeolian" tones, and tongue rams, but they are obscured by a confluence of flute techniques and voice techniques; Balter weaves the text from the first canto of Dante's Paradiso into the texture of the solo flute line, and the performer sings, recites, and whispers the text, sometimes simultaneously with the production of flute tone and other times rapidly alternating between flute sounds and vocal sounds. Balter creates a composite texture using extended flute technique and a vocal part that ranges from breathy, barely-discernible speech to crisp diction, and the result is a combination of techniques that serves the texture, timbre, and theater-driven aesthetic experience of the work. As a result, reviews of this work largely address the work as a complete experience rather than dissecting the individual compositional tools and theatrical elements.

Constructing a reception history of a work that is only three years old may seem premature, but the novel combination of extended flute techniques and voice techniques in addition to the availability of critical language pertaining to the work serve to demonstrate an important point regarding the role of temporality in the reception of contemporary flute worksthe critical language used to describe Descent from Parnassus does not balk at the innovative combination of musical and theatrical techniques in this work but rather embraces the complete experience of the work. This type of critical commentary-previously seen in the 21 st century sources that reference Vox Balaenae, Voice, and Flautina - demonstrates a maturation of critical

\footnotetext{
${ }^{4}$ Molly Sheridan, "Marcos Balter: Hyperactive Unity."
} 
language corresponding to the general passage of time that is not dependent on the amount of time a work has existed. Thus, the critical language used to describe Descent from Parnassus mirrors 21 st century critical language used to describe Vox Balaene, Voice, and Flautina. The trends that dominate the critical language used to describe Descent from Parnassus include the increased prominence of the performer as a creator and communicator of contemporary music, and the perception of contemporary music as a complete aesthetic experience. Regarding the experience of the work, the criticism strives not for complete comprehension of the work but rather a description of the process toward understanding it. The criticism thus aligns with Balter's perceptions of Twombly's artistic intentions: "What I think that Twombly wants from the listener —it's not fully understanding — but it's the journey toward understanding it."5

\section{Reception History}

Claire Chase premiered Descent from Parnassus on January 27, 2012 in Fullerton Hall at the Art Institute of Chicago on a program which also included Tōru Takemitsu's Toward the Sea arranged for flute and marimba, Steve Reich's Electric Counterpoint arranged for marimba and xylophone, Iannis Xenakis' Dmaathen arranged for flute and percussion, and Chase's signature work: Edgard Varèse's Density 21.5 for solo flute. A review of the documented performances of Descent from Parnassus included in this study reveals Claire Chase to be the only known performer of this work to date-while performances of this work by other flutists might exist, it is also feasible that Chase could be the only flutist to have performed the piece, since it is tailored to her specific abilities as a flutist. Involvement as a crucial collaborative partner in the creation of Descent from Parnassus has allowed her to discuss the work with both descriptive musical vocabulary and insights into the demanding combinations of techniques. A number of articles and interviews pertaining to Descent from Parnassus give Chase's words a platform for reaching a wider audience, and her descriptions of the work demonstrate her ability to communicate contemporary music not only through performance but also language.

\footnotetext{
5 Nadia Sirota, "Meet the Composer: Marcos Balter: Failure is an Option," WQXR Q2 Music. Published October 30, 2014. http://www.wqxr.org/\#!/story/meet-composer-marcos-balter-show/
} 
In Chicago Magazine's “Top Five Things to Do This Weekend” published on January 25, 2012, Heather Youkhana features Chase's weekend performance schedule, including the premiere of Descent from Parnassus. Chase provides background information on the composition regarding the connection between Balter's work and Twombly's painting and explains that she and Balter spent hours look at the painting and "imagining ways that it could come alive sonically in space."6 Regarding the theatrical aspect of the composition, she states, "This performance involves me speaking, whispering, sometimes screaming at the top of my lungs, and hyperventilating," and she concludes, "This will take the cake for the craziest thing I've done in public." "In this brief excerpt, Chase draws an extra-musical connection to Twombly's The First Part of the Return from Parnassus, demonstrates her competency in communicating the details of the composition through language, and suggests that the novelty of the work stretches her abilities as a performer to an unprecedented level.

The Chicago Reader also published a preview of the premiere, wherein Peter Margasak quotes Chase's detailed explanation of the work, a description included in a blog post on the ICE website. While the intended audience of the International Contemporary Ensemble blog is likely people familiar with contemporary classical music, Margasak's decision to quote Chase in the Chicago Reader - the readership of which is less likely to be intimately acquainted with the niche market of contemporary classical music_-suggests a confidence in Chase's ability to communicate both the complexity of Balter's score in performance and the overall aesthetic of the piece through comprehensible vocabulary. Chase explains that in Descent from Parnassus, Balter asks her to recite the Dante text into, over, and through the instrument, and she elaborates that the text recitation is "sometimes in conjunction with difficult played passages (a physically impossible act, but the effort to achieve it produces fascinating results), and other times in rapid succession with flute notes, creating a contrapuntal texture." 8 The focus of her description is

\footnotetext{
${ }^{6}$ Chicago Magazine, “Top Five Things to Do This Weekend," Chicago Magazine, January 25, 2012. http:// www.chicagomag.com/Radar/Chicago-Guide/January-2012/Top-Five-Things-to-Do-This-Week/.

7 Ibid.

8 Peter Margasak, “Claire Chase premieres a Marcos Balter work inspired by Cy Twombly,” Chicago Reader, January 26, 2012. http://www.chicagoreader.com/Bleader/archives/2012/01/26/claire-chase-premieres-amarcos-balter-work-inspired-by-cy-twombly.
} 
twofold: first, the composite texture of the flute and voice lines that transcends the realm of modern extended techniques; second, the difficulty of executing this music, which is so extreme as to be, at times, admittedly and intentionally impossible. Chase's performance thus becomes a journey toward realizing an act that is physically impossible, which reflects in a different and unexpected way Balter's perception of Twombly's works as a "journey toward understanding." Chase describes her process of approaching a score with intentionally impossible passages:

There is nowhere to breathe, so I've chosen to inhale certain spoken or sung pitches instead of exhaling them, so as to eliminate any break between the lines - this sounds really cool, but the act dramatically increases your chances of literally choking. So, the piece requires some choking-management techniques. ${ }^{9}$

This description of the process of approaching Balter's unique compositional language gives Descent from Parnassus a certain allure for those familiar with this article-audiences who read Chase's description before encountering the work are subsequently more aware of her attempt to realize physically impossible acts and perhaps become more cognizant of her journey through the score.

Chase is also consulted as an authority on Descent from Parnassus on the Marcos Balter episode of Q2 Music's Meet the Composer podcast. Host Nadia Sirota cites the work as an example of the influence of visual art on Balter's compositional approach, and after a discussion of Balter's attraction to Twombly, Sirota brings Chase into the conversation. Chase describes Balter's novel approach to the use of text with the flute, but she prefaces her discussion of their collaborative exploration of flute techniques with a revealing statement: "He's constantly expanding the languages of the instruments that he uses, and he's constantly expanding my vocabulary as a flutist." ${ }^{10}$ Chase's use of the words "languages" and "vocabulary" in reference to instrumental technique suggests a linguistic connection to the critical language used to describe Descent from Parnassus - it is possible to view the evolution of 21 st century critical commentary as a reflection of expanding instrumental language and vocabulary.

\footnotetext{
${ }^{9}$ Peter Margasak, "Claire Chase premieres a Marcos Balter work inspired by Cy Twombly."

${ }^{10}$ Nadia Sirota, "Meet the Composer: Marcos Balter: Failure is an Option."
} 
Though Chase's ability to verbally communicate Descent from Parnassus has played an undoubtedly important role in the work's reception history, reviews that analyze her ability to communicate the work through performance contain equally significant language that largely references the overall experience of the work. In their review of the premiere of Descent from Parnassus, Larry and Arlene Dunn cite a Twombly quotation in which the artist said of his own work, "It's more like I'm having an experience than making a picture."11 Similar to Twombly's belief that his artistic output was more about the process than the product, Balter's unconventional expansion of instrumental language and vocabulary is process-driven. The resulting compositional language surpassed the realm of standard extended techniques, and the transcendent experience is undergone not only by the composer and the performer but also the audience. Larry and Arlene Dunn's review of Descent from Parnassus explains that the workmuch like Twombly's painting — is about "having an experience" that "transports you into some parallel consciousness." 12 In an attempt to decipher the extended flute techniques and theatrical vocal elements of the score, they list a catalogue of timbres including "overlapping lines of notes, recitations of Dante, groans, howls, pops, clicks, whistles, and simply the vital act of breathing in and out across the flute's aperture." 13 They assert that the amplification reinforced the "otherworldliness of the experience," and they conclude, "Then, it was over. The trance broken, we were dazzled, exhausted, enlightened. We knew, no . . . felt, that we had just traveled somewhere in time and space we had not been before." 14 In reference to the musical elements of the work, the Dunns describe the sound of the techniques rather than the techniques themselves -while this might ordinarily suggest a lack of mature musical vocabulary, in this instance, it is perhaps a more appropriate description of Balter's timbre and texture-driven compositional

\footnotetext{
${ }^{11}$ Randy Kennedy, “American Artist Who Scribbled a Unique Path,” New York Times, July 5, 2011, http:// www.nytimes.com/2011/07/06/arts/cy-twombly-american-artist-is-dead-at-83.html as quoted in Larry and Arlene Dunn, "Claire Chase @ AIC: Return from Parnassus [Review]," International Contemporary Ensemble Blog, February 4, 2012. http://iceorg.org/index.php/blog/post/claire-chase-aic-return-from-parnassus-review.

${ }^{12}$ Larry and Arlene Dunn, "Claire Chase @ AIC: Return from Parnassus [Review]," International Contemporary Ensemble Blog, February 4, 2012. http://iceorg.org/index.php/blog/post/claire-chase-aic-return-fromparnassus-review.

${ }^{13}$ Ibid.

${ }^{14}$ Ibid.
} 
language that defies categorization. Regarding the experience of the work, references to otherworldliness, enlightenment, and transcending time and space suggest that Descent from Parnassus is a journey beyond the physical realm.

Themes of process, journey, and transcendence also appear in the Dunns' interview with contemporary music and art advocate Scott J. Hunter for the contemporary classical music blog $I$ Care If You Listen. The impetus for the interview was the debut of Hunter's first curated gallery exhibition at the Andrew Rafacz Gallery in Chicago which focused on the concept of "gesture" in art. When asked how "gesture" ties music and art together, Hunter responded with a reference to Descent from Parnassus. He explains that the work "interweaves vocal and tonal gestures, evoking a progression across time and space. Moments within the piece radiate emotionsadness, anger, fear - much as each gesture in Twombly's painting guides the viewer down a multilayered path." ${ }^{15}$ Hunter suggests that Balter's unique combination of flute and voice gestures creates a journey across time and space and guides the observer through a complex emotional experience.

The last set of critical reviews pertaining to Descent from Parnassus are by the same critic for the same publication but offset by nearly a year. Chris Sienko for the Chicago-based web publication Gapers Block reviewed the premiere of the work, and he also reviewed the International Contemporary Ensemble's performance at the Chicago Museum of Contemporary Photography on December 8, 2012; the program featured works by Brazilian composers including Alexandre Lunsqui's Topografia de Un Caminho Andado for bass flute, Daniel Puig's Caotrios for two flutes and horn, Arthur Kampela's Not I for solo horn and light, and Marcos Balter's Passará for tape, Edgewater for alto and bass flutes, and Descent From Parnassus. Sienko's review concerning the premiere predominantly focuses on the execution of Chase's dual role as both a flutist and a vocalist. He states:

Chase acts as both speaker and performer, simultaneously - no predictable recite-playrecite alternating here. Claire speaks Dante's words through the flute, sometimes

\footnotetext{
${ }^{15}$ Larry and Arlene Dunn, "5 Questions to Scott J. Hunter (contemporary music and art advocate)," I Care If You Listen, April 1, 2013. http://www.icareifyoulisten.com/2013/04/5-questions-to-scott-j-hunter-contemporarymusic-and-art-advocate/.
} 
embellished with pitched notes, sometimes singing through it, her breathless delivery spilling forth without rests. ${ }^{16}$

By specifying that the interplay of flute sounds and vocal sounds is unpredictable, Sienko suggests that Balter's approach to combining these elements is uniquely realized. Regarding Chase's performance, reference to Chase as both speaker and performer effectively captures the theatrical nature of the work, and the phrase "breathless delivery" evokes images of the performer attempting to execute this physically impossible score.

Sienko's second review of the ICE concert at the Museum of Contemporary Photography is much more experience-driven. Sienko notes that the intimacy of the venue significantly heightened the overall effect of Descent from Parnassus and that the echo of the amplification in this space gave Chase's “declamatory trills, shouts, and sighs the effect of a Greek chorus (what are they doing here in Dante's stomping ground of Italy?), while the flute again floats wispy clouds of melody onto the tempestuous mass of text." 17 Rather than overtly stating the ways in which Balter combines extended flute techniques and theatrical vocal elements, Sienko regards them as a simultaneous happening - the imagery of flute sound floating on top of the frenetic recitation of the text highlights the simultaneous occurrence of these events and thus addresses the unique composite experience of these elements. Regarding the overall aesthetic of the work and the audience's reaction, Sienko states, “At times resembling the Spectral school of Eastern European heavy-hitters like Ana-Maria Avram and Iancu Dumitrescu, Descent from Parnassus brought the house down." 18 By likening Balter's compositional language to that of the Spectral school, Sienko emphasizes the role of timbre in Balter's works, and the overwhelmingly positive audience reaction as described by Sienko suggests that perhaps Descent from Parnassus offers an experience that transcends the need to comprehend the complex texture of interwoven flute and voice techniques.

\footnotetext{
16 Chris Sienko, “To Twombly (Timeless),” Gapers Block, January 25, 2012. http://gapersblock.com/ transmission/2012/01/25/to twombly timeless/

${ }^{17}$ Chris Sienko, "Review: ICE's 'Passará' at the Museum of Contemporary Photography," Gapers Block, December 11, 2012. http://gapersblock.com/transmission/2012/12/11/ review ices passara at the museum of contemporary photography/.

18 Ibid.
} 
Though the work is only three years old, reviews of Descent from Parnassus demonstrate a mature critical language that focuses on the overall experience of the work akin to 21 st century reviews of Vox Balaenae, Voice, and Flautina, thus demonstrating that the developmental arc of critical language used to describe contemporary flute works is linked to the general passage of time and not the amount of time a particular work has existed. Regarding the communication of contemporary music, the role of the performer as co-creator and the increased ability of the performer to communicate contemporary music through not only performance but also through language demonstrates an evolution in the interaction between composers, performers, and audiences. Considering these 21st century developments, it is not surprising that Balter's emphasis on timbre and texture — as demonstrated in Descent from Parnassus — would demand the expansion of instrumental language and vocabulary. However, what is remarkable is the concurrent expansion of critical language, especially the manner in which a critical focus on the transcendental aesthetic experience of Descent from Parnassus reflects Balter's parallel transcending of the modern canon of extended techniques in unprecedented combinations of flute and voice. 


\section{Chapter 6: Synthesis of Trends}

An analysis of the reception history of George Crumb's Vox Balaenae, Tōru Takemitsu's Voice, Karlheinz Stockhausen's Flautina, and Marcos Balter's Descent from Parnassus reveals general trends in critical language used to describe contemporary flute works that can be categorized by decade: a grappling for language to describe extended techniques in the 1970s, emergence of more accurate vocabulary coupled with overt negative criticism in the 1980s, a blend of musical and metaphorical language despite a marked drop off in documented performances in the 1990s, and a focus on extra-musical concerns and the overall experience of the work in the 21 st century. In particular, language of the 21 st century describes the transcendent experience of Vox Balaenae, notions of virtuosity and specialism in contemporary music performance as they pertain to Voice, the interplay of music and theater in Flautina, and the avant-garde as a journey toward understanding as demonstrated through Descent from Parnassus. Though realized through slightly different permutations, all of these 21 st century topics address the complete experience of contemporary classical flute works, and this trend that bridges four works with different composition dates demonstrates a maturation of critical language that is linked to the general passage of time rather than the amount of time a work has existed.

A reception history of Vox Balaenae reveals a linear narrative that traverses attempted descriptions of the timbral effects from the earliest performances in the 1970s, overt negative criticism of the 1980s, the combination of technical and metaphorical language in the 1990s, and emphasis on creating a transcendent experience in the 2000s. A reception history of Voice reveals a concurrent linear narrative that includes negligible mentions of the work in the 1970s, recognition of the theatrical elements of the work within negative criticism in the $1980 \mathrm{~s}$, descriptions of Japanese-inspired extended techniques as communicated through a Western instrument in the 1990s, and the emergence of a mature critical vocabulary coupled with notions of virtuosity and specialism in contemporary music performance in the 21 st century. While the exact details of each work's critical language developmental arc differ slightly, the basic trends in the reception history of these two conceptually similar works are remarkably alike. Early 
encounters with the two works differ the most, and this is likely due to the comparative length of each work-Vox Balaenae is a 20-minute chamber work that has often been the central work on the program, and Voice is a solo flute work that is less than eight minutes. While early reviews of Vox Balaenae demonstrate a grappling for vocabulary, mentions of Voice in early reviews are negligible and provide little insight. For both works, the negative criticism of the 1980s was largely directed at the composers' theatrical specifications, or the seemingly contrived nature of the extended techniques, or both. Despite a marked drop off in documented performances of Vox Balaenae and Voice in the 1990s, reviews of both works began to combine musical and metaphorical language to describe the effect of the perhaps no longer shocking extended techniques. In the 21 st century, critical language used to describe both works focused on the overall experience of the piece, but in different manifestations - reviews of Vox Balaenae describe the notion of transcendence while reviews of Voice discuss notions of virtuosity and specialism in contemporary music performance.

With these narrative arcs established, it is possible to weave the fractured reception history of Flautina into this context in order to confirm trends from these studies and assert the role of temporality in the reception of contemporary flute works. Flautina premiered in Vienna in 1989 on the brink of a decade-long drop off in documented performances of contemporary flute works, and it is quite possible that the first performance of the work in the United States did not occur until 1996. However, in the 21 st century, critical language used to describe Flautina regards the work as a charming and comprehensible interplay of music and theater, thus demonstrating a comparable focus on the overall experience of the work. Similarly, criticism pertaining to Descent from Parnassus illuminates the process-driven approach to both Balter's compositional style and Twombly's artistic intentions and regards the overall experience of the work as a journey that transcends the need to comprehend the complexity of Balter's novel extended technique language.

Additionally, a reception history of these works demonstrates the gradual emergence of a canon of standard extended techniques and a more consistent vocabulary for identifying these techniques that have remained in constant demand. Reviews of Vox Balaenae correctly identify harmonics, singing while playing, and glissandi; reviews of Voice cite microtones, multiphonics, 
key clicks, singing while playing, timbral trills, and harmonics; and reviews of Flautina mention key clicks, residual tones, flutter tonguing, and timbral trills. Due to the novel combination of flute and voice techniques in Descent from Parnassus, reviews of this work do not attempt to identify the individual components - rather they focus on the composite experience of the flute and voice techniques.

Constructing a reception history of these works also reveals the performer to be a key component in the evolution of interactions between composers, performers, and audiences as it relates to the performance aesthetic of contemporary music as mediated through both performance and language. The function of the performer as a link between composer intent and the audience reception has been strengthened over the past 45 years with the emergence of performers as co-creators in addition to the increased ability of the performer to verbally communicate contemporary music. This heightened ability stems from a more active role in the creative compositional process and the rise of digital media as a platform for discussing contemporary music. With the exception of Vox Balaenae, all of the works in this study were the product of a direct composer-performer collaboration-Takemitsu composed Voice for Aurèle Nicolet, Stockhausen composed Flautina for Kathinka Pasveer, and Balter composed Descent from Parnassus for Claire Chase. Contemporary performers have turned to these performers who worked directly with the composers for interpretive guidance and information about the work. This study did not uncover English-language commentary from Nicolet or Pasveer regarding their respective works, but Chase's descriptions of Descent from Parnassus significantly contribute to the work's reception history. Published interviews with additional performers outside of the aforementioned list have also demonstrated a growing platform for performers' descriptions of contemporary flute works in lieu of descriptions by reviewers.

A comparative analysis of the reception history of Vox Balaenae, Voice, Flautina, and Descent from Parnassus reveals trends to suggest that composers, performers, and audiences alike have all generally become more comfortable with the discussion of extended techniques in contemporary flute works over the past several decades rather than this familiarity specifically corresponding to the amount of time that a work has existed. This criticism subsequently highlights the emergence of a common language used to identify and discuss extended 
techniques as well as the formation of a canon of what are considered to be standard extended techniques. Viewing contemporary flute works of the past 45 years through a historiographical reception history lens places these works within a greater societal context that considers the way in which people engage with contemporary music through performance and language and thus illuminates the development of a mature and consistent critical language. 


\section{Bibliography}

Adams, Martin. "Susan Doyle (flutes)/Patrick Zuk (piano) Bank of Ireland Arts Centre." The Irish Times, November 6, 1996.

_. "Susan Doyle (flutes)/William Butt (cello)/Alison Thomas (piano) Bank of Ireland Arts Centre." The Irish Times, November 8, 1999.

Ahrens, Frank. "Under Threat of Closing, N.Y. Sun Hunts for Capital." Washington Post, September 4, 2008.

Babbitt, Milton. "Who Cares if You Listen?” High Fidelity Magazine 8, no. 2 (1958).

Banno, Joe. “At Kennedy Center, A Whale of a Recital.” Washington Post, November 15, 2005.

Barrett, Richard. "'Montag Aus LICHT' at the Holland Festival.” Tempo, no. 166 (September 1988): 43-45. http://www.jstor.org/stable/945909.

Blyth, Alan. "East and West at the Round House." The Times, May 5, 1973.

Brookes, Stephen. "Tōru Takemitsu, Timelessly Contemporary." The Washington Post, October $11,2005$.

Cariaga, Daniel. "Solo Flutist Stone Intrigues With Stockhausen Works." Los Angeles Times, October 1, 1996.

Chicago Magazine. "Top Five Things to Do This Weekend." Chicago Magazine, January 25, 2012. http://www.chicagomag.com/Radar/Chicago-Guide/January-2012/Top-FiveThings-to-Do-This-Week/.

Clarke, Colin. "Voices in the Wind: Flutist Leonard Garrison on recording contemporary works." Fanfare, January/February 2015.

Cohen, David. George Crumb: A Bio-Bibliography. Westport: Greenwood Press, 2002.

Cope, David. New Directions in Music, 5th ed. Dubuque: Brown, 1989.

Crumb, George. Vox Balaenae for Three Masked Players. New York: Edition Peters, 1971.

Crutchfield, Will. “Operaworks Performs 3 Pieces by Crumb.” New York Times, October 3, 1984.

Da Capo Chamber Players. "Da Capo's 'Water Music." da capo Program Notes, http://www.da-capo.org/html/program_notes $1 . h t m$. 
Dammann, Guy. "Chroma chamber ensemble—review." The Guardian, November 8, 2010.

Dierks, Donald. “Music Changed His Life.” San Diego Union, March 15, 1981.

Dobrin, Peter. "Sights Accompany Sounds in Chamber Series." Philadelphia Inquirer, January 23, 1996.

Dunn, Larry and Arlene. "5 Questions to Scott J. Hunter (contemporary music and art advocate)," I Care If You Listen, April 1, 2013. http://www.icareifyoulisten.com/ 2013/04/5-questions-to-scott-j-hunter-contemporary-music-and-art-advocate/.

—_. "Claire Chase @ AIC: Return from Parnassus [Review]." International Contemporary Ensemble Blog, February 4, 2012. http://iceorg.org/index.php/blog/post/claire-chase-aicreturn-from-parnassus-review.

Fefferman, Stanley. “Montreal Stockhausen Project @ New Music Concerts.” Showtimemagazine.ca, November 16, 2008. http://www.showtimemagazine.ca/?p=236.

Garrison, Leonard. "Jennings and Wincenc in Concert." The National Flute Association Convention Chronicles, August 2011. http://www.nfaonline.org/Annual-Convention/ Convention-Chronicles/Convention-Chronicle.aspx?ChronicleID=142.

Gill, Dominic. "Takemitsu.” The Financial Times, May 8. 1973.

Gold, Jamie. "Vox Balaenae.” Washington Post, October 2, 1981.

Gorman, Todd. Review of Voices in the Wind. American Record Guide, November 2014.

Grames, Ronald. Review of Voices in the Wind. Fanfare, January/February 2015.

Griffes, Paul. "A strong team / Review of Music Projects with Bernas at the Almeida." The Times, February 15, 1988.

Hasse, Jean. "Flautist has an Extensive Repertoire." The Bristol Post, September 9, 2010.

Henahan, Donal. “Crumb’s Touch.” New York Times, October 12, 1972.

"Inventive Voice of the Whale." New York Times, April 7, 1973.

Herman, Kenneth. “Delicacy Marks UCSD Concert.” San Diego Union, March 4, 1981. 
Hodges, Nicolas. Review of Flute Music: In Freundschaft, Piccolo, Amour, Susanis Echo, Xi, Zungenspitzentanz, Flautina, Ypsilon, Kathinkas Gesang. Musical Times Vol. 134, No. 1801 (March 1993): 155. http://www.jstor.org/stable/1193872.

Holland, Bernard. "A Flutist Pushing the Edge to Find a Graceful Resolution." New York Times, September 18, 2006.

International Contemporary Ensemble. "A posthumous homage." International Contemporary Ensemble Blog, January 16, 2012. http://iceorg.org/index.php/blog/post/a-posthumoushomage.

Kennedy, Randy. “American Artist Who Scribbled a Unique Path.” New York Times, July 5, 2011.

Kenyon, Nicholas. “Aldeburgh Festival.” The Times, June 19, 1984.

Kozinn, Allan. "Return to Crumb's World, With Crumb Along for the Ride." New York Times. October 28, 2008.

—. Review of Beginnings by eighth blackbird. New York Times, June 27, 2004.

Library of Congress. "New York Camerata in Concert.” Information bulletin, March 10, 1972. http://www.mocavo.com/Library-of-Congress-Information-Bulletin-10-Mar-1972Volume-31/648333/4.

Lombardi, Jessica. "The Montreal Stockhausen Project.” The Live Music Report, November 15, 2008. http://www.thelivemusicreport.com/2008/November/StockhausenProject $\underline{\text { nov08.html }}$

Mann, William. “Takemitsu: Round House.” The Times, May 7, 1973.

Margasak, Peter. "Claire Chase premieres a Marcos Balter work inspired by Cy Twombly." Chicago Reader, January 26, 2012. http://www.chicagoreader.com/Bleader/archives/ 2012/01/26/claire-chase-premieres-a-marcos-balter-work-inspired-by-cy-twombly.

May, Amy. "First Caramel Classics Night." About Amy May. http://www.aboutamymay.com/ news/first-karamel-classics-night.

McCardell, Charles. “Santa Fe Chamber Music.” Washington Post, March 18, 1991.

McLellan, Joseph. "20th Century Consort.” Washington Post, November 23, 1993.

—. "Apple Hill: An Ode to The Ocean.” Washington Post, October 17, 1988. 
__. "Chamber Music Society of Lincoln Center." Washington Post, April 4, 1983.

Nordlinger, Jay. “A Poised and Capable Young Flutist.” The New York Sun, March 9, 2006.

O’Connell, Clive. “Stockhausen Makes Local Contact.” The Age, November 8, 1996.

Poole, Elissa. "Composer on a mission; George Crumb's work - always about something —was fashionable 20 years ago. Now he is back on radar screens." Globe and Mail, February 2, 2000 .

—. "Tribute to Takemitsu Showcases Decades of Musical Innovation." Globe and Mail, February 22, 1997.

Powell, Ardal. The Flute. New Haven: Yale University Press, 2002.

Reinthaler, Joan. "From National Musical Arts, a Blue Light Special." Washington Post, February 22, 2000.

__. "Voice of the Whale." Washington Post, March 18, 1972.

Riner, Nicole. Review of Voices in the Wind. Flutist Quarterly, Winter 2015.

Rockwell, John. “Chamber Quintet's Particular Program.” New York Times, December 17, 1989.

__. "Encounters with Takemitsu." Los Angeles Times, February 10, 1972.

Rothstein, Edward. "Chamber Music Society Plays 'Vox Balaenae.” New York Times, April 4, 1983.

__. "Concert: 'Microtonal' by Newband.” New York Times, April 29, 1982.

Ruhe, Pierre. "Chamber Players Tap into Nature's Rhythms." The Atlanta Journal-Constitution, April 2, 2001.

Saville, Jonathan. "Sound of Structure." San Diego Reader, March 12, 1981.

Scheinin, Richard. "Tight, Fearless Sextet's Musical Declaration.” San Jose Mercury News, February 8, 2005.

Schiffer, Brigitte. “"East-West' by Dreamtiger.” Tempo, New Series, No. 136 (Mar., 1981) via http://www.jstor.org/stable/946384 
Sheridan, Molly. “Marcos Balter: Hyperactive Unity.” New Music Box, April 17, 2013. http://www.newmusicbox.org/articles/marcos-balter-hyperactive-unity/.

Siddons, James. Tōru Takemitsu: A Bio-Bibliography. Westport: Greenwood Press, 2001.

Sienko, Chris. "Review: ICE's 'Passará' at the Museum of Contemporary Photography." Gapers Block, December 11, 2012. http://gapersblock.com/transmission/2012/12/11/ review ices_passara_at the museum of contemporary photography/.

—. "To Twombly (Timeless).” Gapers Block, January 25, 2012. http://gapersblock.com/ transmission/2012/01/25/to twombly timeless/

Sirota, Nadia. "Meet the Composer: Marcos Balter: Failure is an Option.” WQXR Q2 Music. Published October 30, 2014. http://www.wqxr.org/\#!/story/meet-composer-marcos-baltershow/.

Smith, Rowena. "New Music Experience, Queen’s Hall, Edinburgh 4/5." The Guardian, October $31,2009$.

Smoller, David. “Composer Takemitsu Breaks Mold, Reconciles Cultures.” Los Angeles Times, March 11, 1981.

Snapp, Martin. "Cahill Cornucopia Comes to Music Fans in March.” Contra Costa Times, February 28, 2003.

Steinberg, Russell. "'Meta-Counterpoint' in George Crumb's Music: Exploring Surface and Depths in Vox Balaenae (Voice of the Whale)." In George Crumb \& The Alchemy of Sound, edited by Steven Bruns and Ofer Ben-Amots. Colorado Springs: Colorado College Music Press, 2005.

Stockhausen, Karlheinz. Flautina. Kürten: Stockhausen-Verlag, 1995.

Tamer, Joyce. "WCMS sparkles with 'Water Games."” Telegram \& Gazette, November 17, 2014.

The New Zealand Herald. "Karlheinz Company at Auckland University Music Theatre." The New Zealand Herald, May 20, 2009.

Thow, Penny. "Voice Interpreted." The Mercury, May 10, 2007.

UC San Diego. “New York Camerata to appear.” Press release, November 7, 1968.

Vance, David. “All Things Bright and Beautiful Hit the Stage for a Finale to Remember.” Sydney Morning Herald, October 16, 2001. 
West Virginia Public Broadcasting, "A conversation with George Crumb” YouTube. Flash video file. https://www.youtube.com/watch? $\mathrm{v}=5 \times \mathrm{xo8SHjTxpc}$.

Whittington, Stephen. “A Startling Assortment.” The Advertiser, October 19, 1993. 